Front cover. Bed-load sample collection at Sheyenne River above Diversion near Horace, North Dakota, during the 2010 spring high-flow event (photograph by Robert A. Blanchard, U.S. Geological Survey). 


\section{Sediment Concentrations, Loads, and Particle-Size Distributions in the Red River of the North and Selected Tributaries near Fargo, North Dakota, during the 2010 Spring High-Flow Event}

By Robert A. Blanchard, Christopher A. Ellison, Joel M. Galloway, and Dennis A. Evans

Prepared in cooperation with the U.S. Army Corps of Engineers, St. Paul District

Scientific Investigations Report 2011-5064 


\section{U.S. Department of the Interior \\ KEN SALAZAR, Secretary \\ U.S. Geological Survey \\ Marcia K. McNutt, Director}

\section{U.S. Geological Survey, Reston, Virginia: 2011}

For more information on the USGS - the Federal source for science about the Earth, its natural and living resources, natural hazards, and the environment, visit http://www.usgs.gov or call 1-888-ASK-USGS.

For an overview of USGS information products, including maps, imagery, and publications, visit http://www.usgs.gov/pubprod

To order this and other USGS information products, visit http://store.usgs.gov

Any use of trade, product, or firm names is for descriptive purposes only and does not imply endorsement by the U.S. Government.

Although this report is in the public domain, permission must be secured from the individual copyright owners to reproduce any copyrighted materials contained within this report.

Suggested citation:

Blanchard, R.A., Ellison, C.A., Galloway, J.M., and Evans, D.A., 2011, Sediment concentrations, loads, and particlesize distributions in the Red River of the North and selected tributaries near Fargo, North Dakota, during the 2010 spring high-flow event: U.S. Geological Survey Scientific Investigations Report 2011-5064, 27 p. 


\section{Contents}

Abstract

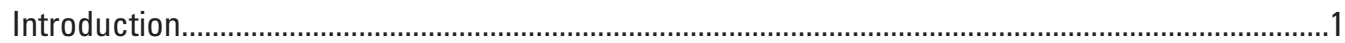

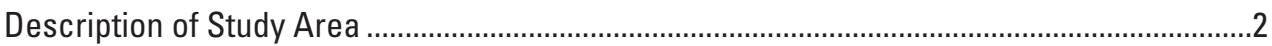

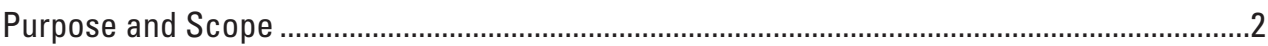

Methods of Study

Sediment-Data Collection ...................................................................................................

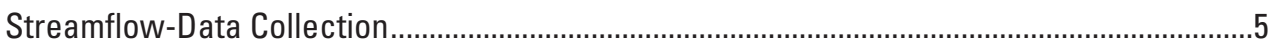

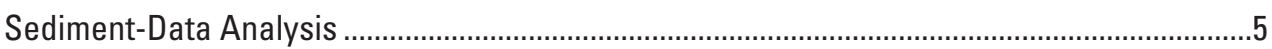

Suspended-Sediment Concentration ........................................................................................

Suspended-Sediment Load, Bedload, and Total Sediment Load .....................................................

Particle-Size Distribution...................................................................................................

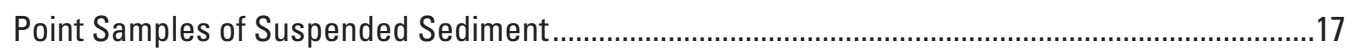

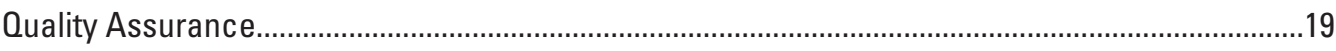

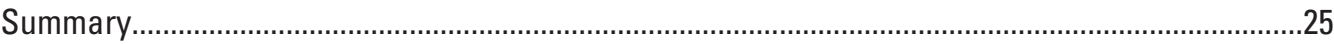

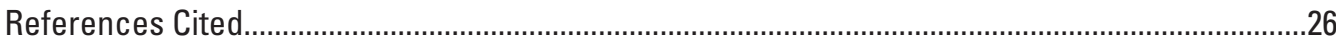

\section{Figures}

1. Map showing location of selected sites in the study area...............................................

2. Graph showing suspended-sediment concentrations in the Red River of the North and selected tributaries near Fargo, North Dakota, during the 2010 spring high-flow event.

3. Graphs showing time series of streamflow and suspended-sediment concentrations in the Red River of the North and selected tributaries near Fargo, North Dakota, during the spring 2010 high-flow event.

4. Graphs showing suspended-sediment concentration and streamflow relations in the Red River of the North and selected tributaries near Fargo, North Dakota, during the 2010 spring high-flow event.

5. Graph showing estimated total event sediment loads in the Red River of the North and selected tributaries near Fargo, North Dakota, during the 2010 spring high-flow event.

6. Graphs showing time series of streamflow and total sediment discharges for the Red River of the North and selected tributaries near Fargo, North Dakota, during the 2010 spring high-flow event. .....

7. Graphs showing suspended-sediment concentrations collected at various depths above the channel thalweg in the Red River of the North and selected tributaries near Fargo, North Dakota, during the 2010 spring high-flow event.

\section{Tables}

1. Streamflow and sediment data collection sites in the Red River of the North and selected tributaries near Fargo, North Dakota, during the 2010 spring high-flow event.

2. Streamflow, suspended-sediment concentrations, fall diameters, and sieve diameters for samples collected in the Red River of the North and selected tributaries near Fargo, North Dakota, during the 2010 spring high-flow event. 
3. Kendall-Sen test correlation results between suspended-sediment concentration and streamflow for samples collected in the Red River of the North and selected tributaries near Fargo, North Dakota, during the 2010 spring high-flow event......

4. Sediment discharges for the Red River of the North and selected tributaries near Fargo, North Dakota, during the 2010 spring high-flow event.

5. Input data for the Modified Einstein Procedure for samples collected in the Red River of the North and selected tributaries near Fargo, North Dakota, during the 2010 spring high-flow event.

6. Sieve diameters and mass of bedload samples for samples collected in the Red River of the North and selected tributaries near Fargo, North Dakot, during the 2010 spring high-flow event,

7. Sieve diameters of bed-material samples collected in the Red River of the North and selected tributaries near Fargo, North Dakota, during the 2010 spring high-flow event.

8. Fall diameter, sieve diameter, and suspended-sediment concentration for samples collected at discrete vertial depth in the Red River of the North and selected tributaries near Fargo, North Dakota, during the 2010 spring high-flow event.

9. Results of quality-assurance samples for suspended-sediment concentration and bedload mass for selected samples collected during the 2010 spring high-flow event at the Red River of the North and selected tributaries near Fargo, North Dakota ..........25

\section{Conversion Factors, Abbreviations, and Datums}

\begin{tabular}{lll}
\hline \multicolumn{1}{c}{ Multiply } & \multicolumn{1}{c}{ By } & \multicolumn{1}{c}{ To obtain } \\
\hline inch (in.) & Length & \\
millimeter (mm) & 2.54 & centimeter $(\mathrm{cm})$ \\
foot (ft) & 0.03937 & inch (in.) \\
mile (mi) & 0.3048 & meter $(\mathrm{m})$ \\
\hline & 1.609 & kilometer $(\mathrm{km})$ \\
\hline square mile $\left(\mathrm{mi}^{2}\right)$ & Area & \\
\hline & 2.590 & square kilometer $\left(\mathrm{km}^{2}\right)$ \\
\hline quart $(\mathrm{qt})$ & Volume & \\
gallon (gal) & 0.9464 & liter $(\mathrm{L})$ \\
& 3.785 & liter $(\mathrm{L})$ \\
\hline cubic foot per second $\left(\mathrm{ft}^{3} / \mathrm{s}\right)$ & Flow rate & \\
\hline & 0.02832 & cubic meter per second $\left(\mathrm{m}^{3} / \mathrm{s}\right)$ \\
\hline gram $(\mathrm{g})$ & Mass & \\
ton, short $(2,000 \mathrm{lb})$ & 0.03527 & ounce, avoirdupois $(\mathrm{oz})$ \\
ton per day (ton/d) & 0.9072 & megagram $(\mathrm{Mg})$ \\
\hline Temper & 0.9072 & metric ton per day \\
\hline
\end{tabular}

Temperature in degrees Celsius $\left({ }^{\circ} \mathrm{C}\right)$ may be converted to degrees Fahrenheit $\left({ }^{\circ} \mathrm{F}\right)$ as follows: ${ }^{\circ} \mathrm{F}=\left(1.8 x^{\circ} \mathrm{C}\right)+32$

Vertical coordinate information is referenced to North American Vertical Datum of 1988 (NAVD 88).

Horizontal coordinate information is referenced to North American Datum of 1983 (NAD 83).

Concentrations of chemical constituents in water are given either in milligrams per liter (mg/L) or micrograms per liter ( $\mu \mathrm{g} / \mathrm{L})$. 


\title{
Sediment Concentrations, Loads, and Particle-Size Distributions in the Red River of the North and Selected Tributaries near Fargo, North Dakota, during the 2010 Spring High-Flow Event
}

\author{
By Robert A. Blanchard, Christopher A. Ellison, Joel M. Galloway, and Dennis A. Evans
}

\section{Abstract}

A study by the U.S. Geological Survey, in cooperation with the U.S. Army Corps of Engineers was conducted during the 2010 spring high-flow event to determine sediment concentrations, loads, and particle-size distributions at six sites in the Red River of the North and selected tributaries near Fargo, North Dakota. Suspended-sediment (point and integrated samples), bed-material, and bedload samples were collected at the six sites at various time intervals during the high-flow event.

Suspended-sediment concentrations varied spatially during the 2010 spring high-flow event sampling period. Suspended-sediment concentrations in the Red River of the North (Red River) ranged from 74 to 156 milligrams per liter at Red River near Christine and from 81 to 154 milligrams per liter at Red River near Fargo. In comparison, the suspended-sediment concentrations ranged from 476 to 1,120 milligrams per liter at the Sheyenne River above Diversion and from 505 to 957 milligrams per liter in the Sheyenne River below Diversion.

Streamflow and suspended-sediment concentration data collected during the 2010 spring high-flow event demonstrated that the timing of the peak in suspended-sediment concentration varied in relation to the peak in streamflow among the six sites. At the Red River near Christine, Red River near Fargo, Sheyenne River below Diversion, and Maple River, the suspended-sediment concentration peak occurred after the streamflow peak. It appears that the peak suspended-sediment concentration occurred simultaneously with the streamflow peak at Sheyenne River above Diversion and before the streamflow peak at the Wild Rice River.

Total sediment loads measured during the 2010 spring high-flow event mainly were composed of suspended sediment and were the greatest at the Sheyenne River above Diversion compared to the loads in the Red River near Christine, Red River near Fargo, Sheyenne River below Diversion, Maple River, and the Wild Rice River. Total measured bedload contributed less than 1 percent of the total sediment load for all of the sites. The total event sediment load ranged from 31,600 tons at the Maple River to 143,100 tons at the Sheyenne River above Diversion.

The timing of the peak in sediment discharge in relation to the peak in streamflow varied among the six sites during the 2010 spring high-flow event. Peak-sediment discharges occurred simultaneously with, or possibly prior to, the streamflow peak in the Red River near Christine, Red River near Fargo, Sheyenne River above Diversion, Maple River, and the Wild Rice River. The peak-sediment discharge occurred a day after the peak streamflow in the Sheyenne River below Diversion, and the Sheyenne River above Diversion peak-sediment discharge occurred a day before the peak-sediment discharge occurred at the Sheyenne River below Diversion, and simultaneously with the peak streamflow.

For the majority of all samples collected during the 2010 spring high-flow event, with the exception of sites on the Sheyenne River, more than 90 percent of the measured suspended sediment was composed of fine-grained particles (less than 0.062 millimeters). Particle-size analyses from bedload samples indicated material in the Red River and the Maple River was coarser than material in the Sheyenne River and the Wild Rice River. The bed material demonstrated a different areal distribution of particle sizes than observed in the bedload, with the coarsest material found at the Wild Rice River and the finest material at the Sheyenne River below Diversion.

\section{Introduction}

The Red River of the North (Red River) has exceeded the National Weather Service flood stage of 18 feet in 47 of the past 108 years for the Fargo-Moorhead metropolitan area, and every year from 1993 through 2010 (U.S. Army Corps of Engineers, 2010). Flooding in the Fargo-Moorhead metropolitan area typically occurs during the spring high-flow event in late March and early April coinciding with the annual 
snowmelt pattern. Current flood-management activities in the Fargo-Moorhead metropolitan area such as sandbagging, levee systems, and the Horace-Fargo diversion channel have reduced the effects of flooding. Even with these activities, average annual flood damages are estimated at over $\$ 187$ million (U.S. Army Corps of Engineers, 2010). As the FargoMoorhead metropolitan area continues to grow, future average annual flood damages are estimated at over $\$ 195$ million if no additional actions for flood management are taken to reduce flooding (U.S. Army Corps of Engineers, 2010). To reduce the flooding effects, a feasibility study was begun in the FargoMoorhead metropolitan area in 2008 under direction of the U.S Army Corps of Engineers (USACE), St. Paul District, and the sponsor cities of Fargo, N. Dak., and Moorhead, Minn., to investigate measures to reduce flood risk and analyze the potential for Federal participation in implementing a flood risk management project (U.S. Army Corps of Engineers, 2010). The study analyzed a number of possible types of measures and alternative plans that could reduce the flood risk in the Fargo-Moorhead metropolitan area. These measures and alternative plans were analyzed for effectiveness, environmental effects, social effects, acceptability, risk, separable mitigation, and cost effectiveness. An array of potential alternatives was considered, including nonstructural flood proofing, diversion channels, levee/floodwall systems, and flood storage. Construction of a North Dakota Diversion Channel around the Fargo-Moorhead metropolitan area was chosen from these plans for further analysis.

Natural resource agencies were concerned about possible geomorphic effects of the proposed diversion project in the Fargo-Moorhead metropolitan area (U.S. Army Corps of Engineers, 2010). Site-specific information available on sediment transport and riverine geomorphic processes are very limited and have prohibited accurate geomorphic modeling to address those concerns. To provide accurate and reliable information on sediment transport, the U.S. Geological Survey (USGS) in cooperation with the USACE conducted a study in the spring (March-April) of 2010 to examine sediment concentrations, loads, and particle-size distributions in the Red River and its western tributaries near the Fargo-Moorhead metropolitan area. The 2010 spring high-flow event provided a unique opportunity to sample sites during high-flow conditions when most sediment generally is transported (Guy, 1970). The USGS collected suspended-sediment, bed-material, and bedload samples at six sites during the 2010 spring high-flow event.

\section{Description of Study Area}

The Red River begins at Wahpeton, N. Dak., and flows north into Canada before emptying into Lake Winnipeg, Manitoba. Meandering for approximately 450 river miles over a flat lacustrine plain, composed primarily of clay-rich, unconsolidated (erodible) glacial sediments, the shallow channel of the Red River forms the boundary between North Dakota and
Minnesota (U.S. Army Corps of Engineers, 2010). The drainage area for the Red River Basin is about 40,200 square miles and encompasses parts of eastern North Dakota, northwestern Minnesota, and northeastern South Dakota in the United States and southern Manitoba in Canada.

The Red River flows through several urban areas along its path including the cities of Fargo, N. Dak., and Moorhead, Minn., Grand Forks, N. Dak., and East Grand Forks, Minn., and Winnipeg, Manitoba. Western tributaries to the Red River near the Fargo-Moorhead metropolitan area include the Wild Rice, Sheyenne, and Maple Rivers (fig. 1). Because of the northerly flow of the Red River, the low gradient of the Red River Basin, and the shallow river channel, the timing of spring thaw and snowmelt can greatly exacerbate flooding. Snow in the upstream part of the Red River Basin begins to melt first, whereas areas downstream remain mostly frozen. This snowmelt pattern can cause ice jams to form and subsequent backwater (water that is retarded, backed up, or turned back in its course because of an obstruction or an opposing current) to occur as flood flows move north. The annual spring high-flow event attributed to this snowmelt pattern varies in the extent of its magnitude from year to year with frequent exceedance of established flood stages within the Red River Basin.

The study area was located in the general vicinity of the Fargo-Moorhead metropolitan area and included selected sites at or near existing USGS streamflow monitoring sites on the western tributaries to the Red River (fig. 1). A total of six sites was sampled for suspended sediment (point and integrated samples), bed material, and bedload. The six sites were selected based on availability of existing streamflow data and project objectives and included: two sites on the Red River, located upstream and downstream from the Fargo-Moorhead metropolitan area; two sites on the Sheyenne River, one upstream from the Sheyenne River diversion channel and one site downstream from the diversion channel; one site on the Maple River near the confluence with the Red River; and one site on the Wild Rice River near the confluence with the Red River (fig. 1, table 1). Although sampling sites on Red River tributaries were selected at locations with existing USGS streamflow monitoring sites, the two sediment data collection sites on the main stem of the Red River were located upstream (Red River near Christine) and downstream (Red River near Fargo) from established streamflow monitoring sites (fig. 1, table 1).

\section{Purpose and Scope}

The purpose of this report is to describe sediment concentrations, loads, and particle-size distribution during the 2010 spring high-flow event at the following selected sites in the Fargo-Moorhead metropolitan area: Red River near Christine, Red River near Fargo, Sheyenne River above Diversion, Sheyenne River below Diversion, Maple River, and, Wild Rice River (table 1). In addition to these sites, Red River near 


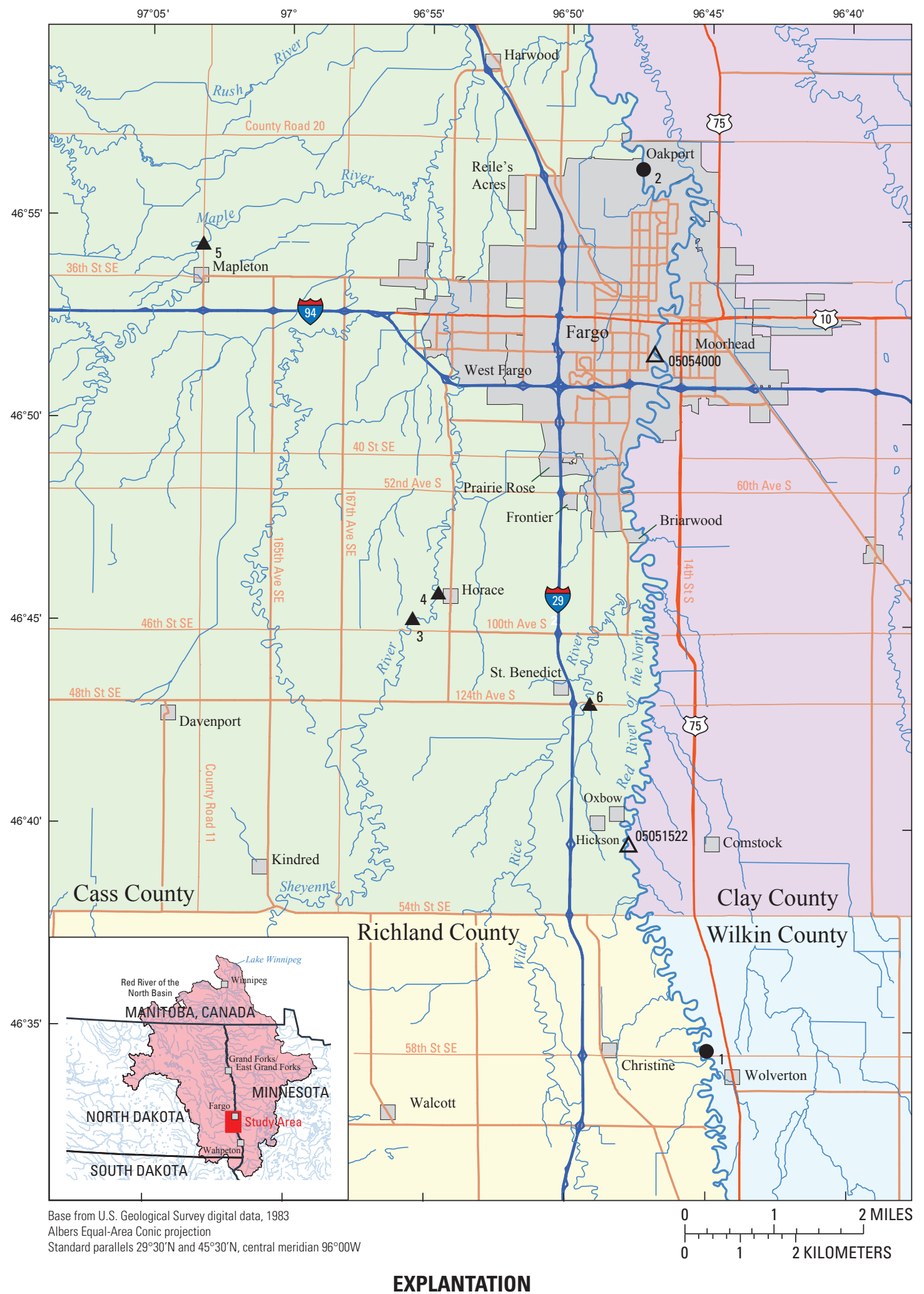

6 $\Delta$ Sediment-sampling and streamflow-monitoring site and identifier

$05051522 \Delta$ Streamflow-monitoring site and identifier

1 Sediment-sampling site and identifier

Figure 1. Location of selected sites in the study area. 
Table 1. Streamflow and sediment data collection sites for the Red River of the North and selected tributaries near Fargo, North Dakota, during the 2010 spring high-flow event.

\begin{tabular}{|c|c|c|c|c|}
\hline $\begin{array}{c}\text { Site } \\
\text { identification } \\
\text { number (fig. 1) }\end{array}$ & $\begin{array}{l}\text { USGS station } \\
\text { number }\end{array}$ & Site description & $\begin{array}{l}\text { Abbreviated site } \\
\text { description }\end{array}$ & Data collected \\
\hline 1 & -- & $\begin{array}{l}\text { Red River of the North near Christine, North } \\
\text { Dakota }\end{array}$ & Red River near Christine & Sediment \\
\hline 05051522 & 05051522 & $\begin{array}{l}\text { Red River of the North near Hickson, North } \\
\text { Dakota }\end{array}$ & Red River near Hickson & Streamflow \\
\hline 2 & -- & Red River of the North near Fargo, North Dakota & Red River near Fargo & Sediment \\
\hline 3 & 05059300 & $\begin{array}{l}\text { Sheyenne River above Sheyenne River Diversion } \\
\text { near Horace, North Dakota }\end{array}$ & $\begin{array}{l}\text { Sheyenne River above } \\
\text { Diversion }\end{array}$ & Streamflow, sediment \\
\hline 4 & 05059330 & Sheyenne River at Horace, North Dakota & $\begin{array}{l}\text { Sheyenne River below } \\
\text { Diversion }\end{array}$ & Streamflow, sediment \\
\hline
\end{tabular}

Hickson and Red River at Fargo also were selected to provide streamflow data for computation of sediment discharge at Red River near Christine and Red River near Fargo, respectively. Sediment samples were collected from March 17, 2010 (when the spring high-flow event began), to April 7, 2010 (when streamflow had receded). The data from the samples provided information on transport and distribution of sediment at the six selected sites. Comparisons of the data collected were made in the report to show general non-statistical differences of particle-size distribution among the sites. Additionally, the report describes whether the Modified Einstein Procedure (MEP) could be used to predict sediment discharge. Results from the MEP calculation of bedload discharge were compared to measured bedload discharge to show general differences between the two approaches.

\section{Methods of Study}

The following sections describe methods used for the collection and analysis of sediment samples and measurement of streamflow. Data were collected by the USGS in the general vicinity of the Fargo-Moorhead metropolitan area and included selected sites at or near existing USGS streamflow monitoring sites. A total of six sites were sampled, including two sites on the Red River, located upstream and downstream from the Fargo-Moorhead metropolitan area; two sites on the Sheyenne River, one upstream from the Sheyenne River diversion channel and one site below the diversion channel; one site on the Maple River near the confluence with the Red River; and one site on the Wild Rice River near the confluence with the Red River (fig. 1, table 1).

\section{Sediment-Data Collection}

Suspended-sediment (point and integrated samples), bed-material, and bedload samples were collected at six sites near the Fargo-Moorhead metropolitan area at various time intervals during the 2010 spring high-flow event. In general, suspended-sediment and bed-material samples were collected every day or every 2 days during the rise and peak of the streamflow hydrograph at each site and at a less frequent interval during the recession of the streamflow hydrograph at each site. Bedload samples and point samples for suspended sediment were collected on a less frequent basis ( 2 to 3 days) then the integrated suspended-sediment and bed-material samples.

Integrated suspended-sediment concentration (SSC) samples were collected on a frequent basis during the spring 2010 high-flow event to estimate the amount of suspended material that was being transported past the six sites during the event. To collect samples that represent the vertical and horizontal variability of suspended sediment in the stream channels, samples were collected using depth-integrated samplers (Davis, 2005) and the equal-width increment (EWI) method (Edwards and Glysson, 1999). The EWI method involved the collection of vertically integrated, isokinetic (velocity entering the sampler nozzle was the same as the velocity of the stream) samples at 10 equal intervals across the stream cross section. The SSC samples were then composited in a 2-gallon or $31 / 2$-gallon plastic churn splitter and processed into pint-size glass bottles. Replicate samples were collected with approximately 20 percent of the regular samples. Replicate samples were obtained for the SSC samples by removing a representative volume of water from the churn splitter concurrently with the regular sample. 
Bed-material samples were collected with every SSC sample for use in estimating the total sediment load in the channel at the six sites. Bed-material samples were collected using a US BMH-60 or a US BM-54 sampler, depending on depths and velocities in the stream cross section (Davis, 2005). The samplers were designed to penetrate the streambed and completely enclose a sample at depths of $13 / 4$ inches and 2 inches, respectively. According to Edwards and Glysson (1999), it is suggested that 10-20 uniformly spaced bedmaterial samples be collected from each stream cross section. For this study, the bed-material samples were collected at three locations in the stream cross section because of project time constraints and low variability in sediment composition across the streambed. The bed-material samples were then composited into a 1-quart plastic container.

Bedload samples were collected to estimate the sediment transport near the streambed at the six sites. Bedload samples were obtained using a cable-suspended Helley-Smith Model 8035 sampler (Davis, 2005). The sampler was designed for orientation in the direction of flow when deployed on the streambed. The Helley-Smith was equipped with a Standard Price AA current meter for measuring point velocity concurrent with the bedload sample collection for use in sedimentdischarge calculations. Bedload samples were collected at 10 equal-width sections across the stream cross section and were then composited in a 1-quart plastic container. Methods for collection of bedload as described by Edwards and Glysson (1999) suggest a minimum of 40 samples be collected using one of three methods: single equal-width-increment method (SEWI), multiple equal-width-increment method (MEWI), or unequal-width-increment method (UWI). An alternative method described by Edwards and Glysson (1999) suggests 20 equal-width sections based on the EWI method when human resources and budget restrictions, as well as hydrologic conditions, may prevent multiple or even single SEWI, MEWI, or UWI type cross-sectional measurements. Because of time constraints in collecting data from the six sites, available crews to collect the data, and the low contribution of bedload to the total sediment discharge, a decision was made to further modify this alternative approach and reduce the amount of bedload samples collected from 20 to 10. Sequential replicate samples were collected with approximately 20 percent of the regular samples and were obtained by independently sampling the stream cross section twice for bedload.

To estimate the vertical distribution of particle sizes and concentrations during the 2010 high-flow event, suspendedsediment samples were collected at discrete vertical points (point samples) at each site at various time intervals during the event. Point samples were obtained using a US P-61-A1 suspended-sediment sampler that is designed to open and close at varying depths in the water column (Davis, 2005). Samples were collected at approximately 20,50 , and 80 percent of the total depth in the water column at the deepest part of the stream cross section (thalweg).

All suspended-sediment, bed-material, and bedload samples were analyzed for particle-size distribution and concentration at the USGS Iowa Water Science Center Sediment Laboratory in Iowa City, Iowa, using methods described in Guy (1969). Some suspended-sediment samples (integrated and point samples) were not analyzed for a full particle-size distribution because of insufficient sediment mass present in the sample. The laboratory reports a fall diameter, which is the diameter of a quartz sphere that would settle at the same speed as the sediment grain in still, distilled water at 24 degrees Celsius. Results from the analysis were stored in the USGS National Water Information System (NWIS) database (http:// nwis.waterdata.usgs.gov/nd/nwis/qw).

\section{Streamflow-Data Collection}

Streamflow data were collected for use with the sediment concentration data to calculate sediment loads. Stream stage was measured continuously at the Red River of the North near Hickson, N. Dak. (USGS station number 05051522), Red River of the North at Fargo, N. Dak. (USGS station number 05054000), the Sheyenne River above Sheyenne River Diversion near Horace, N. Dak. (USGS station number 05059300), Sheyenne River at Horace, N. Dak. (USGS station number 05059330), Maple River below Mapleton, N. Dak. (USGS station number 05060100), and the Wild Rice River near St. Benedict, N. Dak. (USGS station number 464243096495100) (fig. 1, table 1). The continuous stage data were used with instantaneous discharge measurements to compute the continuous streamflow from stage-discharge rating curves using methods described in Rantz and others (1982). Data for stream stage and streamflow were stored in the USGS NWIS database (http://nwis.waterdata.usgs.gov/nd/nwis/qw). Computed streamflow from the monitoring site at the Red River of the North near Hickson, N. Dak. (USGS station number 05051522), was used to compute sediment discharge and loads for Red River near Christine and streamflow from the Red River of the North at Fargo, N. Dak. (USGS station number 05054000), was used to compute sediment discharge and loads for Red River near Fargo.

\section{Sediment-Data Analysis}

The relation between SSC and streamflow was examined to evaluate whether streamflow could be used to predict the sediment discharge. A Kendall-Sen nonparametric test was conducted to evaluate relations between SSC and streamflow using S-Plus statistical analysis software (TIBCO Software Inc., 2010). An advantage of the Kendall-Sen test is greater resistance to outlier effects than the more commonly used Pearson's $r$ correlation coefficient, because the Kendall-Sen test is based on ranks (Helsel and Hirsch, 1992). Measures of correlation are dimensionless and scaled to be in the range of -1.0 to 1.0. A value of 0 indicates no relation between two variables. Relations were considered to be significantly positive (with a value between 0 and 1.0 indicating that SSC increased as streamflow increased) or negative (with a value 
between 0 and -1.0 indicating that SSC decreased as streamflow increased) if the probability (two-sided p-value) of rejecting a correct hypothesis (in this case, no trend) was less than or equal to 0.05 . For the Kendall-Sen test, the data are not assumed to be normally distributed and a linear median estimator of SSC is provided (Sen, 1968).

Daily suspended-sediment discharges were estimated for the six sites using the instantaneous streamflow data and SSC data collected during the 2010 spring high-flow event. Daily sediment discharges were estimated using equation 1 (Porterfield, 1972):

$$
Q_{s}=Q_{w} x C_{s} \times K
$$

where
$Q_{s} \quad$ is the sediment discharge, in tons (English short tons) per day (tons/day),
$Q_{w} \quad$ is the instantaneous streamflow (water discharge), in cubic feet per second $\left(\mathrm{ft}^{3} / \mathrm{s}\right)$,
$C_{s}$ is the $\mathrm{SSC}$, in milligrams per liter $(\mathrm{mg} / \mathrm{L})$, and
$K \quad$ is a coefficient $(0.0027)$ to convert the units of measurement of water discharge and SSC into tons/day and assumes a specific gravity of 2.65 for sediment.

To estimate the total sediment discharge, the bedload component was estimated in addition to the suspendedsediment discharges. One of the most difficult problems encountered in open-channel hydraulics is the determination of the rate of movement of bed material (bedload transport) (Einstein, 1950). Two methods were used to estimate the bedload discharge at each site. The first method was to calculate bedload discharge from the measured data using equation 2 (Edwards and Glysson, 1999):

$$
Q_{b}=K \times\left(W_{T} / t_{T}\right) \times M_{T}
$$

where

$$
\begin{aligned}
& Q_{b} \quad \text { is the bedload discharge, in tons/day, } \\
& K \text { is a conversion factor ( } 0.381 \text { for a } 3 \text {-inch } \\
& \text { nozzle), } \\
& W_{T} \quad \text { is the total width of the stream from which } \\
& \text { samples were collected, in feet, } \\
& t_{T} \quad \text { is the total time the sampler was on the } \\
& \text { streambed, in seconds, computed by }
\end{aligned}
$$

The second method was to develop a model using bed-material particle-size distribution, streamflow, velocity, channel geometry, and water-temperature data to estimate the bedload. Einstein (1950) presented a technique for computing total discharge of sediment of sizes found in appreciable quantities in the streambed. Unfortunately, collection of the data required by Einstein's procedure is very labor intensive and time consuming. Because of this, Colby and Hembree (1955) and Colby and Hubbell (1967) developed a modified version of Einstein's procedure (MEP) that used data from a single cross section to calculate the total sediment discharge for a specific stream reach. The MEP is considered an improvement over the original Einstein method because it is simpler in computation and uses characteristics more readily available from actual stream measurements. The MEP model was implemented using the executable program Bureau of Reclamation Automated Modified Einstein Procedure (BORAMEP) (U.S. Bureau of Reclamation, 2010). Input data needed for the MEP model included streamflow, velocity, channel geometry, water temperature, SSC, and bed-material particle-size distribution data.

Total sediment discharges were estimated for each of the six sites during the sampling period by summing the estimated suspended-sediment discharges and bedload discharges. Daily total sediment discharges were estimated for the sampling period at each site by using linear interpolation between the days when calculated total sediment discharges were available.

\section{Suspended-Sediment Concentration}

Suspended-sediment concentration varied spatially during the 2010 spring high-flow event sampling period. Samples for SSC were collected on a frequent basis to help understand the amount of suspended material transported past the six sites during the event. SSCs of tributary streams were substantially higher than SSCs of the main stem of the Red River, especially at the Sheyenne River sites (fig. 2 and table 2). SSC on the Red River ranged from 74 to $156 \mathrm{mg} / \mathrm{L}$ at Red River near Christine and from 81 to $154 \mathrm{mg} / \mathrm{L}$ at Red River near Fargo. In comparison, the SSC at the Sheyenne River above Diversion ranged from 476 to $1,120 \mathrm{mg} / \mathrm{L}$ and from 505 to $957 \mathrm{mg} / \mathrm{L}$ in the Sheyenne River below Diversion. The Maple River had SSC ranging from 172 to $325 \mathrm{mg} / \mathrm{L}$ and the Wild Rice River had SSC ranging from 136 to $186 \mathrm{mg} / \mathrm{L}$ (fig. 2 and table 2).

Streamflow and SSC data collected during the 2010 spring high-flow event showed that the timing of the peak in SSC varied in relation to the peak in streamflow among the six sites (fig. 3). At the Red River sites, Sheyenne River below Diversion, and the Maple River, the SSC peak occurred after the streamflow peak. However, samples could not be collected on the early rise of the streamflow hydrograph to capture the possible fine sediment loosened by freezing and thawing because of heavy ice flows in the channels at the sampling sites; an early peak may have occurred but was not captured by the sampling. It appears that the peak SSC occurred simultaneously with the streamflow peak at the Sheyenne River above Diversion and before the streamflow peak at the Wild Rice River (fig. 3). Variation in streamflow provides important information for the timing and magnitude of changes 


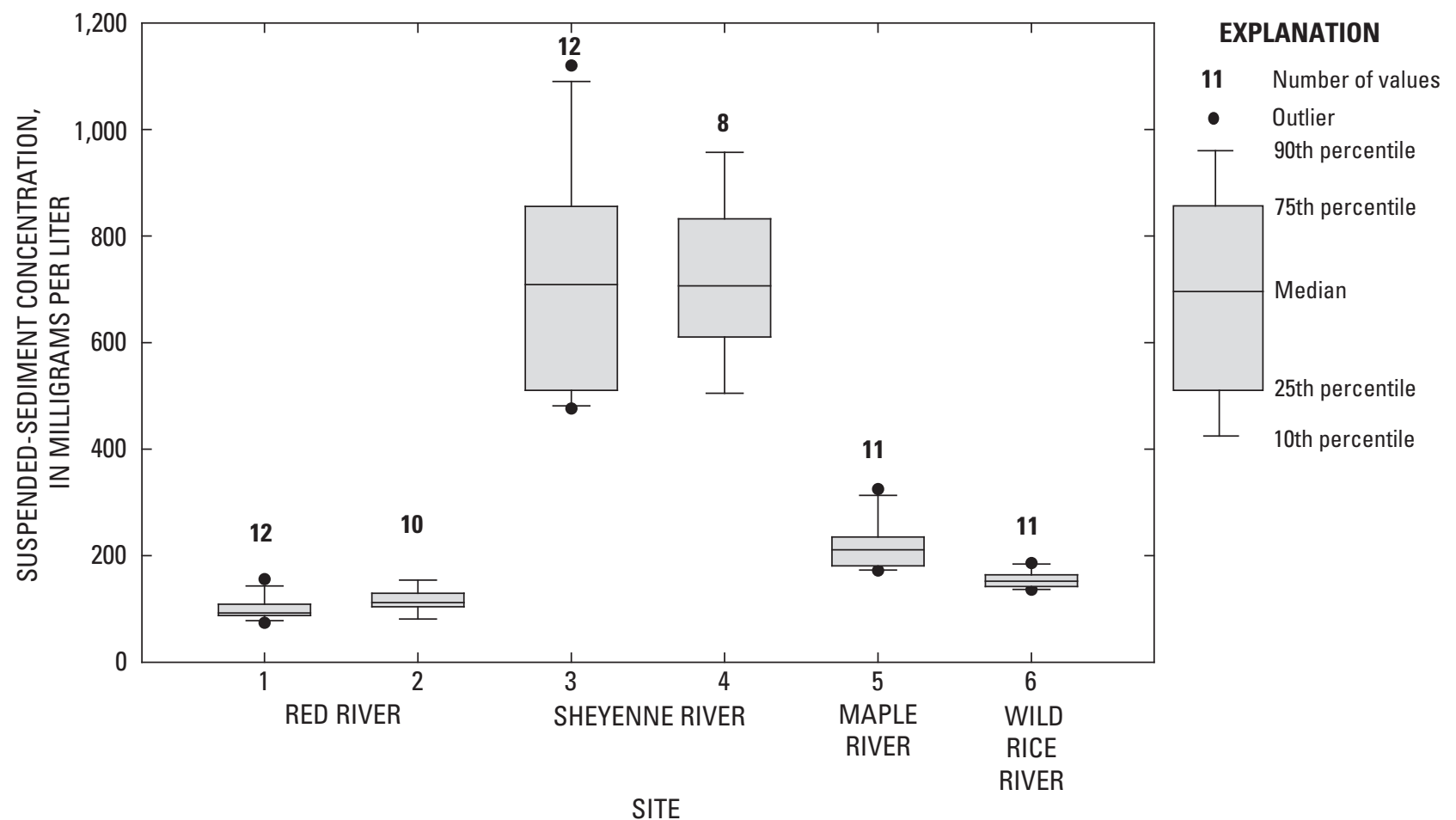

Figure 2. Suspended-sediment concentrations in the Red River of the North and selected tributaries near Fargo, North Dakota, during the 2010 spring high-flow event.

in the sediment concentration of streams. In most rainfall runoff events, it is common for SSC to peak in advance of the hydrograph peak (Guy, 1970). However, the relation between streamflow and SSC during snowmelt generally is different than during periods of runoff from rainfall (Colby, 1963; Guy, 1970). Increases in concentration relative to increases in streamflow are small during snowmelt runoff as compared with rainfall runoff, and large concentration peaks generally do not occur at or near the time of the streamflow peak (Porterfield, 1972). The timing of the streamflow peak is related to the distance between the snowmelt source and the sampling point. The amount of lag between water and SSC peak is a function of the distance between the sampling point and the source of the material.

The evaluation of the relation between SSC and streamflow reveals that only two of the six sites demonstrated significant correlations between SSC and streamflow for the range of streamflow observed during the monitoring period (fig. 4 and table 3). The relation between streamflow and sediment concentration is known to vary widely from stream to stream and within varying cross sections of the same stream. The variation and range of concentration during any snowmelt or runoff event may differ from the concentrations during other periods, even though streamflow may be identical or similar (Porterfield, 1972). Both Sheyenne River sites had SSC data that were positively correlated to streamflow (p-value less than 0.05 ) during the sampling period (table 3 ). The lack of a significant relation between SSC and streamflow at the other four sites (sites 1,2,5, and 6) may be attributed to a combination of complex factors, which include a high variability of SSC and the limited range of streamflow observed during snowmelt runoff. Inputs of sediment to streams are highly variable over space and time, which tends to affect the SSC and streamflow relation (Uhrich and Bragg, 2003; Guy, 1970). There is an unknown element to many sediment generation processes, which may be initiated or accelerated by flood events, snowmelt runoff, and freeze-thaw actions, all of which can cause erosion of channel bank and bed material and produce irregular pulses of sediment into the channel (Charlton, 2009). These complex rates and controls on sediment generation are influenced by the Red River Valley's unique climate, hydrology, geology, topography, and land-use activities. Studies indicate that SSC collected over a wide range of streamflow can improve the relation between SSC and streamflow (Guy, 1970; Porterfield, 1972; Tornes, 1986).

\section{Suspended-Sediment Load, Bedload, and Total Sediment Load}

Total sediment loads measured during the 2010 spring high-flow event at the Red River and its tributaries near the Fargo-Moorhead metropolitan area were mainly composed of suspended sediment and were the greatest at the Sheyenne River above Diversion (site 3) compared to the loads in the Red River (sites 1 and 2), Sheyenne River below Diversion (site 4), Maple River (site 5), and the Wild Rice River 
Table 2. Streamflow, suspended-sediment concentrations, fall diameters, and sieve diameters for the Red River of the North and selected tributaries near Fargo, North Dakota, during the 2010 spring high-flow event.

[ft $\mathrm{ft}^{3} \mathrm{~s}$, cubic feet per second; mm, millimeter; mg/L, milligram per liter; +, rising stage; -, falling stage; IM, insufficient material for analysis; --, no value]

\begin{tabular}{|c|c|c|c|c|c|c|c|c|}
\hline \multirow{2}{*}{$\begin{array}{c}\text { Date } \\
\text { (month/day/ } \\
\text { year) }\end{array}$} & \multirow{2}{*}{$\begin{array}{c}\text { Stage } \\
\text { condition }\end{array}$} & \multirow{2}{*}{$\begin{array}{l}\text { Streamflow } \\
\left(\mathrm{ft}^{3} / \mathrm{s}\right)\end{array}$} & \multirow{2}{*}{$\begin{array}{l}\text { Suspended- } \\
\text { sediment } \\
\text { concentration } \\
\text { (mg/L) }\end{array}$} & \multicolumn{4}{|c|}{$\begin{array}{l}\text { Suspended-sediment fall diameter (values in } \\
\text { percent finer than size) }\end{array}$} & \multirow{2}{*}{$\begin{array}{l}\text { Percent finer than } \\
\text { suspended sediment } \\
\text { sieve diameter } \\
\text { of } 0.062 \mathrm{~mm}\end{array}$} \\
\hline & & & & $0.062 \mathrm{~mm}$ & $0.125 \mathrm{~mm}$ & $0.250 \mathrm{~mm}$ & $0.500 \mathrm{~mm}$ & \\
\hline 03/18/2010 & + & 14,700 & 98 & IM & $\mathrm{IM}$ & IM & $\mathrm{IM}$ & 96 \\
\hline 03/20/2010 & + & 14,700 & 93 & IM & IM & IM & $\mathrm{IM}$ & 99 \\
\hline $03 / 22 / 2010$ & - & 8,760 & 87 & IM & IM & IM & IM & 97 \\
\hline 03/23/2010 & - & 7,810 & 87 & IM & $\mathrm{IM}$ & IM & $\mathrm{IM}$ & 97 \\
\hline 03/24/2010 & - & 7,380 & 89 & IM & $\mathrm{IM}$ & IM & $\mathrm{IM}$ & 96 \\
\hline $03 / 25 / 2010$ & - & 6,810 & 90 & IM & IM & IM & IM & 95 \\
\hline 04/01/2010 & - & 4,260 & 92 & 93 & 99 & 100 & 100 & -- \\
\hline $04 / 06 / 2010$ & - & 3,720 & 113 & 89 & 97 & 99 & 100 & -- \\
\hline \multicolumn{9}{|c|}{ Red River of the North near Fargo (site 2) } \\
\hline $03 / 17 / 2010$ & + & 11,800 & 132 & IM & IM & IM & $\mathrm{IM}$ & 96 \\
\hline $03 / 19 / 2010$ & + & 20,200 & 127 & IM & IM & IM & IM & 97 \\
\hline $03 / 21 / 2010$ & + & 21,100 & 120 & IM & $\mathrm{IM}$ & IM & $\mathrm{IM}$ & 97 \\
\hline $03 / 23 / 2010$ & - & 18,900 & 102 & IM & IM & IM & IM & 96 \\
\hline $03 / 23 / 2010$ & - & 18,900 & 112 & IM & IM & IM & IM & 100 \\
\hline $03 / 24 / 2010$ & - & 17,200 & 110 & IM & IM & IM & IM & 96 \\
\hline 03/21/2010 & + & -- & 508 & 78 & 90 & 100 & 100 & -- \\
\hline $03 / 22 / 2010$ & + & 3,680 & 476 & 80 & 92 & 99 & 100 & -- \\
\hline $03 / 23 / 2010$ & + & 3,890 & 870 & 74 & 90 & 100 & 100 & -- \\
\hline 03/24/2010 & + & 4,830 & 1,120 & 71 & 89 & 100 & 100 & -- \\
\hline 03/25/2010 & - & 4,350 & 1,020 & 71 & 86 & 99 & 100 & -- \\
\hline $03 / 26 / 2010$ & - & 4,350 & 813 & 76 & 90 & 99 & 100 & -- \\
\hline $03 / 27 / 2010$ & - & 4,370 & 762 & 73 & 88 & 99 & 100 & -- \\
\hline $03 / 29 / 2010$ & - & 4,320 & 693 & 70 & 86 & 98 & 100 & -- \\
\hline $03 / 31 / 2010$ & - & 4,260 & 725 & 76 & 87 & 100 & 100 & -- \\
\hline $04 / 05 / 2010$ & - & 3,760 & 517 & 82 & 91 & 98 & 100 & -- \\
\hline 04/07/2010 & - & 3,440 & 493 & 84 & 94 & 100 & 100 & -- \\
\hline
\end{tabular}


Table 2. Streamflow, suspended-sediment concentrations, fall diameters, and sieve diameters for the Red River of the North and selected tributaries near Fargo, North Dakota, during the 2010 spring high-flow event.-Continued

$\left[\mathrm{ft}^{3} / \mathrm{s}\right.$, cubic feet per second; mm, millimeter; $\mathrm{mg} / \mathrm{L}$, milligram per liter; +, rising stage; -, falling stage; IM, insufficient material for analysis; --, no value]

\begin{tabular}{|c|c|c|c|c|c|c|c|c|}
\hline \multirow{2}{*}{$\begin{array}{c}\text { Date } \\
\text { (month/day/ } \\
\text { year) }\end{array}$} & \multirow{2}{*}{$\begin{array}{l}\text { Stage } \\
\text { condition }\end{array}$} & \multirow{2}{*}{$\begin{array}{l}\text { Streamflow } \\
\left(\mathrm{ft}^{3} / \mathrm{s}\right)\end{array}$} & \multirow{2}{*}{$\begin{array}{c}\text { Suspended- } \\
\text { sediment } \\
\text { concentration } \\
\text { (mg/L) }\end{array}$} & \multicolumn{4}{|c|}{$\begin{array}{c}\text { Suspended-sediment fall diameter (values in } \\
\text { percent finer than size) }\end{array}$} & \multirow{2}{*}{$\begin{array}{l}\text { Percent finer than } \\
\text { suspended sediment } \\
\text { sieve diameter } \\
\text { of } 0.062 \mathrm{~mm}\end{array}$} \\
\hline & & & & $0.062 \mathrm{~mm}$ & $0.125 \mathrm{~mm}$ & $0.250 \mathrm{~mm}$ & $0.500 \mathrm{~mm}$ & \\
\hline \multicolumn{9}{|c|}{ Sheyenne River at Horace (site 4) } \\
\hline $03 / 24 / 2010$ & + & 2,100 & 602 & IM & IM & IM & IM & 95 \\
\hline $03 / 25 / 2010$ & - & 2,030 & 957 & 78 & 94 & 99 & 100 & -- \\
\hline $03 / 26 / 2010$ & - & 2,000 & 836 & 77 & 94 & 100 & 100 & -- \\
\hline 03/27/2010 & - & 1,990 & 821 & 79 & 88 & 96 & 100 & -- \\
\hline 03/29/2010 & - & 1,980 & 714 & 78 & 94 & 100 & 100 & -- \\
\hline $03 / 31 / 2010$ & - & 1,960 & 699 & 83 & 95 & 100 & 100 & -- \\
\hline $04 / 05 / 2010$ & - & 2,010 & 636 & 83 & 95 & 99 & 100 & -- \\
\hline $04 / 07 / 2010$ & - & 1,940 & 505 & 82 & 95 & 100 & 100 & -- \\
\hline \multicolumn{9}{|c|}{ Maple River below Mapleton (site 5) } \\
\hline $03 / 19 / 2010$ & + & 6,740 & 266 & IM & IM & IM & IM & 98 \\
\hline 03/20/2010 & - & 5,530 & 187 & IM & $\mathrm{IM}$ & IM & $\mathrm{IM}$ & 98 \\
\hline $03 / 21 / 2010$ & - & 4,390 & 172 & IM & $\mathrm{IM}$ & IM & IM & 97 \\
\hline $03 / 22 / 2010$ & - & 3,660 & 190 & IM & $\mathrm{IM}$ & IM & $\mathrm{IM}$ & 97 \\
\hline $03 / 23 / 2010$ & - & 3,210 & 235 & IM & IM & IM & IM & 93 \\
\hline $03 / 24 / 2010$ & - & 2,810 & 227 & IM & IM & IM & $\mathrm{IM}$ & 97 \\
\hline $03 / 26 / 2010$ & - & 2,410 & 220 & IM & $\mathrm{IM}$ & IM & $\mathrm{IM}$ & 97 \\
\hline $03 / 27 / 2010$ & - & 2,190 & 325 & IM & $\mathrm{IM}$ & IM & IM & 86 \\
\hline 03/30/2010 & - & 2,210 & 211 & IM & IM & IM & IM & 98 \\
\hline $04 / 02 / 2010$ & - & 2,150 & 177 & IM & IM & IM & IM & 98 \\
\hline $04 / 06 / 2010$ & - & 1,630 & 181 & 95 & 98 & 100 & -- & -- \\
\hline \multicolumn{9}{|c|}{ Wild Rice River at I-25 near St. Benedict (site 6) } \\
\hline $03 / 18 / 2010$ & + & 7,740 & 186 & $\mathrm{IM}$ & $\mathrm{IM}$ & IM & IM & 98 \\
\hline 03/20/2010 & + & 8,410 & 177 & IM & $\mathrm{IM}$ & IM & IM & 98 \\
\hline $03 / 21 / 2010$ & - & 8,250 & 140 & IM & $\mathrm{IM}$ & IM & $\mathrm{IM}$ & 97 \\
\hline $03 / 22 / 2010$ & - & 7,850 & 164 & 94 & 95 & 100 & 100 & -- \\
\hline $03 / 23 / 2010$ & - & 7,540 & 136 & IM & IM & IM & $\mathrm{IM}$ & 100 \\
\hline $03 / 24 / 2010$ & - & 7,400 & 152 & IM & IM & IM & $\mathrm{IM}$ & 96 \\
\hline $03 / 25 / 2010$ & - & 7,200 & 146 & IM & $\mathrm{IM}$ & IM & $\mathrm{IM}$ & 99 \\
\hline 03/26/2010 & - & 6,970 & 152 & IM & IM & IM & IM & 99 \\
\hline 03/27/2010 & - & 6,840 & 161 & IM & IM & IM & IM & 99 \\
\hline 03/30/2010 & - & 6,330 & 148 & IM & IM & IM & IM & 97 \\
\hline $04 / 01 / 2010$ & - & 5,400 & 142 & IM & $\mathrm{IM}$ & IM & $\mathrm{IM}$ & 97 \\
\hline
\end{tabular}


RED RIVER NEAR CHRISTINE - SITE 1

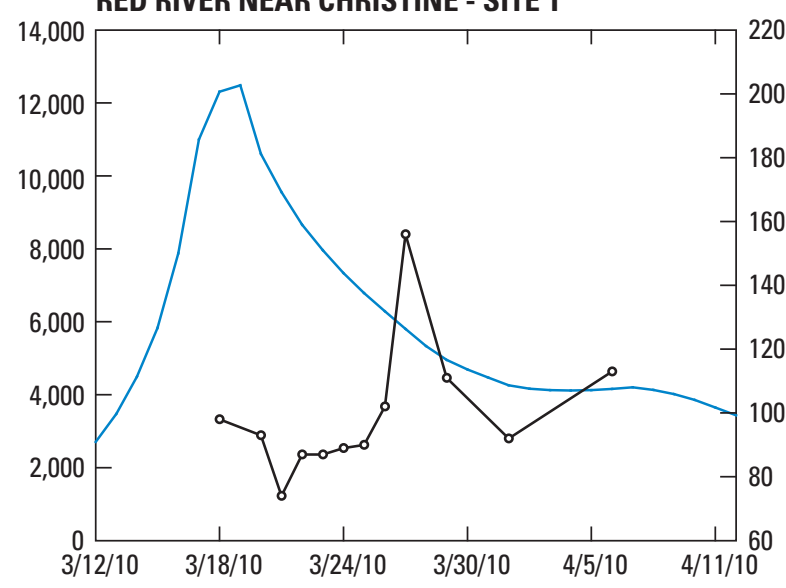

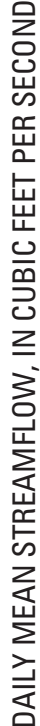
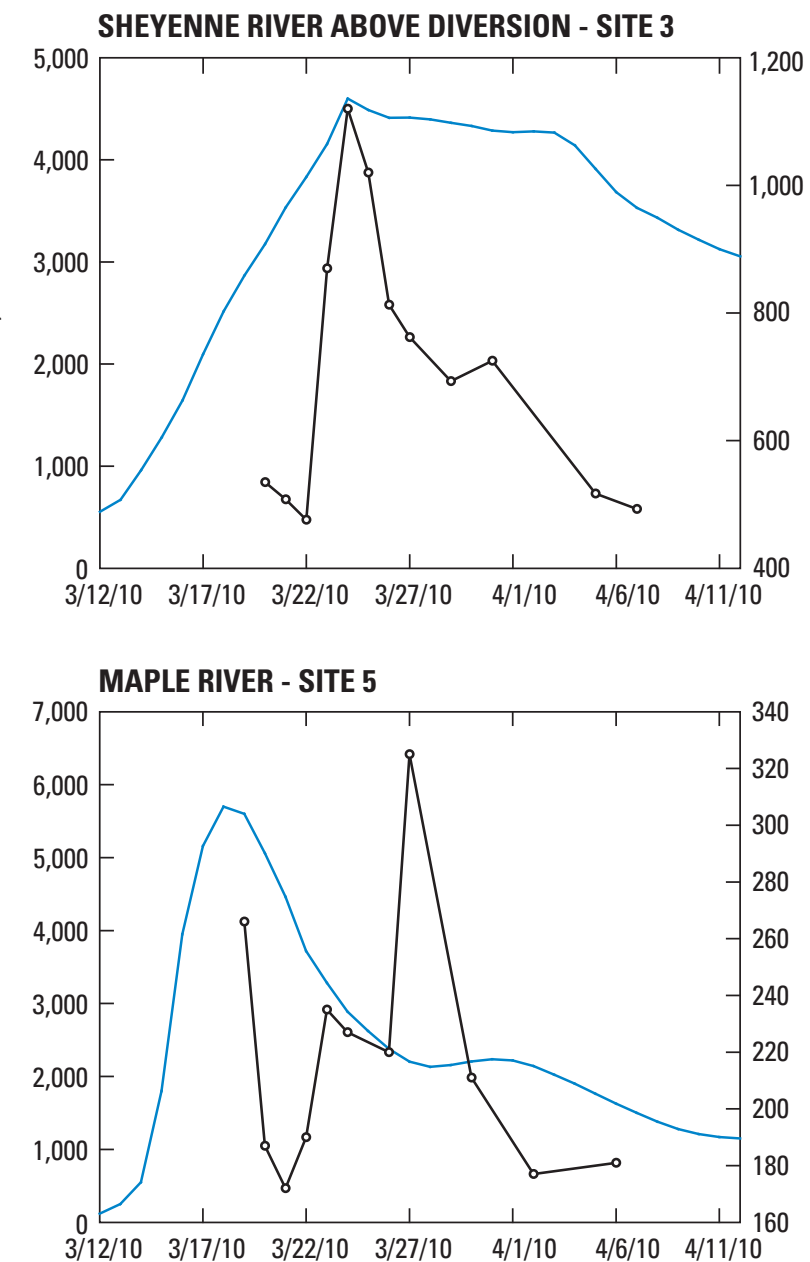

RED RIVER NEAR FARG0 - SITE 2
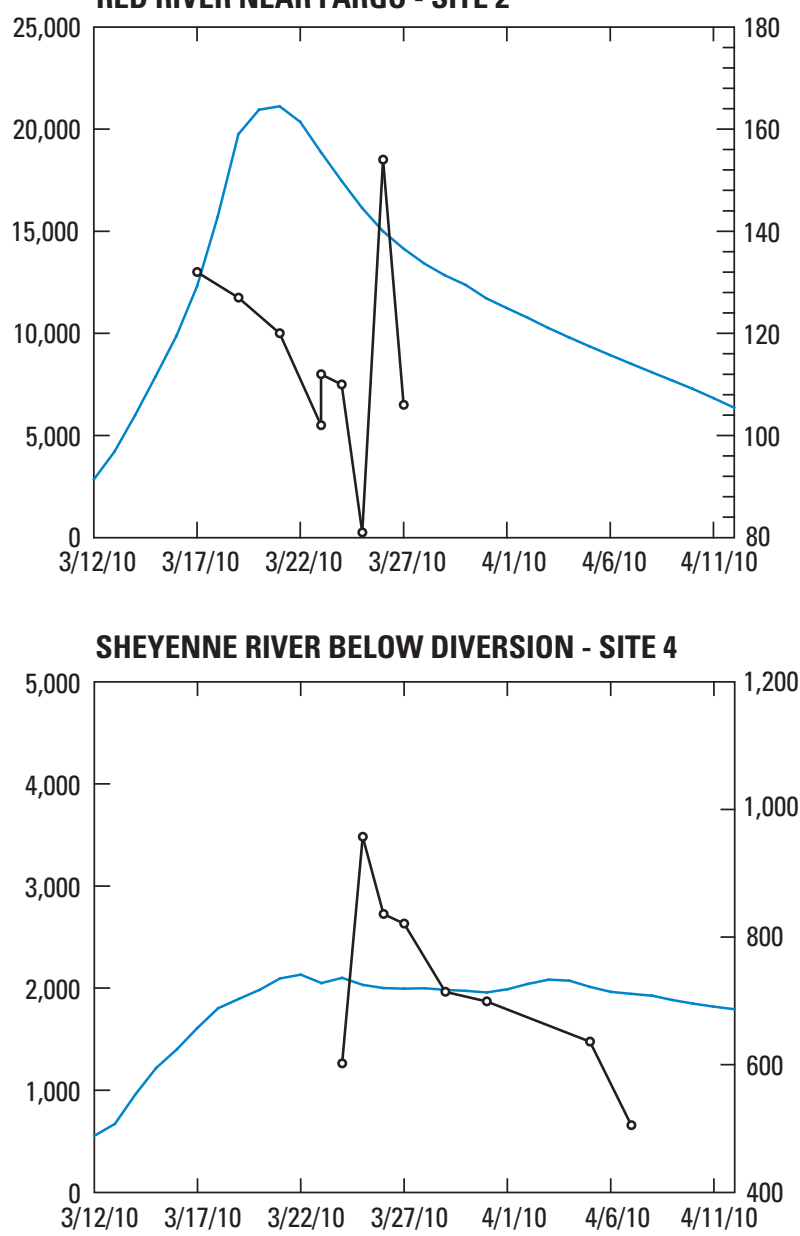

WILD RICE RIVER - SITE 6

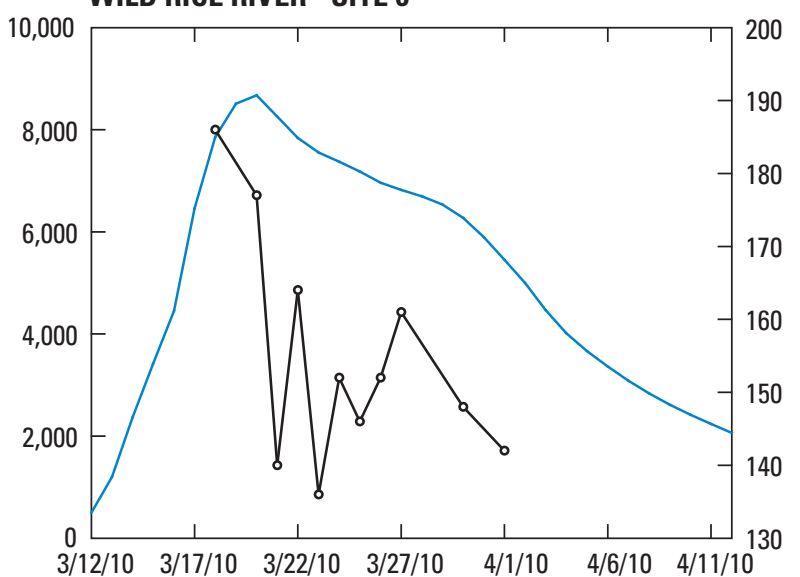

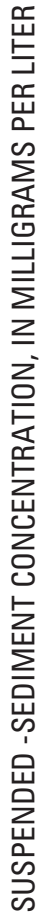

\section{EXPLANATION}

— Daily mean streamflow

$\multimap$ Measured suspended-sediment concentration

Figure 3. Time series of streamflow and suspended-sediment concentrations in the Red River of the North and selected tributaries near Fargo, North Dakota, during the spring 2010 high-flow event. 
Table 3. Kendall-Sen test correlation results between suspended sediment concentration and streamflow for the Red River of the North and selected tributaries near Fargo, North Dakota, during the 2010 spring high-flow event.

[ $\mathrm{ft}^{3} / \mathrm{s}$, cubic feet per second; SSC, suspended sediment concentration; $\mathrm{mg} / \mathrm{L}$, milligrams per liter]

\begin{tabular}{lrrrrr}
\hline \multicolumn{1}{c}{ Site } & Tau & p-value & Slope & $\begin{array}{c}\text { Median } \\
\text { streamflow } \\
\left(\mathbf{f t}^{3} / \mathbf{s}\right)\end{array}$ & $\begin{array}{c}\text { Median } \\
\text { SSC } \\
(\mathbf{m g} / \mathbf{L})\end{array}$ \\
\hline Red River of the North near Christine (site 1) & -0.42 & 0.06 & -0.0026 & 7,095 & 92 \\
Red River of the North near Fargo (site 2) & -.07 & .90 & -.0007 & 16,500 & 116 \\
Sheyenne River above Diversion near Horace (site 3) & .56 & .02 & .3513 & 4,260 & 709 \\
Sheyenne River at Horace (site 4) & .50 & .01 & .3758 & 1,995 & 706 \\
Maple River below Mapleton (site 5) & .09 & .76 & .0044 & 2,810 & 211 \\
Wild Rice River near St. Benedict (site 6) & .22 & .39 & .0063 & 7,400 & 152 \\
\hline
\end{tabular}

(site 6) (fig. 5). Total measured bedload for the event ranged from 7 tons at the Sheyenne River below Diversion (site 4, March 24-April 7) to 186 tons at the Red River near Christine (site 1, March 18 to April 6) (fig. 5). Contribution of total measured bedload during the event for each of the sites was less than 1 percent of the total sediment load calculated for each of the sites (fig. 5). The low bedload transport rates, which are proportional to streamflow and channel slope, may be attributable, in part, to low gradients in the basin, overbank flooding, and low stream velocities. The calculated sediment load during the entire event ranged from 31,600 tons at the Maple River (site 5, March 19-April 6) to 143,100 tons at the Sheyenne River above Diversion (site 3, March 20-April 7) (fig. 5). The Red River's total event sediment load ranged from 37,600 tons at Red River near Christine (site 1, March 18-April 6) to 76,300 tons at Red River near Fargo (site 2, March 17-31). The Wild Rice River's total sediment load for the event was calculated to be 45,400 tons (site 6, March 18-April 1) and the Sheyenne River below Diversion's total sediment load for the event was calculated to be 57,500 tons (site 4, March 24April 7) (fig. 5).

The timing of the peak in sediment discharge in relation to the peak in streamflow varied among the six sites during the 2010 spring high-flow event (fig. 6). Peak sediment discharges occurred simultaneously with, or possibly prior to, the streamflow peak at the Red River near Christine, Red River near Fargo, the Sheyenne River above Diversion, the Maple River, and Wild Rice River. Samples could not be collected on the early rise of the streamflow hydrograph because of heavy ice flows in the channels, so a peak in sediment discharge may have occurred prior to the streamflow peak. In particular, the Red River near Christine, Maple River, and the Wild Rice River may have had a peak in sediment discharge prior to the streamflow peak because the greatest sediment discharges were associated with the first samples collected, compared to all the samples collected at each site, with values of 3,950 tons/day, 4,840 tons/day, and 3,900 tons/day, respectively (table 4). The peak sediment discharge occurred a day after the peak streamflow at the Sheyenne River below Diversion with a value of 5,250 tons/day (fig. 6). In comparison, the
Sheyenne River above Diversion had a peak sediment discharge of 14,600 tons/day on March 24, a day before the peak sediment discharge occurred at the Sheyenne River below Diversion, and simultaneously with the peak streamflow at both of the Sheyenne River sites (fig. 6).

A comparison was made using the two methods described in this report (equation 2 and BORAMEP) for estimating bedload discharge to determine whether a model (MEP model) could be used to determine bedload instead of collecting bedload samples for future investigations. Numerous errors resulted from difficulties inherent with collecting bedload samples using a portable sampler. When a bedload sampler rests on the streambed, the flow pattern and the bedload discharge in the vicinity of the sampler are altered to an unknown extent. The degree to which the bedload discharge is altered depends upon many factors, such as stream velocity and depth, the magnitude of the bedload discharge, and the particle size of the bedload (Hubbell, 1964; Edwards and Glysson, 1999). To obtain the most accurate bedload-discharge measurements, bedload samplers were designed to minimize errors in order to collect large and small particles, accumulate and retain bedload particles, and orient vertically and horizontally in the streambed for stability so that all particles have an equal opportunity for entrance into the sampler (Hubbell, 1964). Unfortunately, with current methods, it is extremely difficult to collectively satisfy all of these criteria and thus a level of uncertainty continues to exist.

Bedload discharge estimated from physical samples collected in the 2010 spring high-flow event and from the MEP model did not compare well between the two methods (table 4). Input data used for the model included streamflow, velocity, channel geometry, water temperature, SSC, and bed-material particle-size distribution data (tables 2, 4, 5, and 6). The MEP model overestimated bedload discharge by a relatively large amount for every comparison except for March 18, 2010, at Red River near Christine. The mean differences between the MEP bedload discharge and physically sampled bedload discharge ranged from 30 tons/day (MEP bedload discharge is larger than physically sampled bedload discharge by a factor of 3.1) at Red River near Christine to 
Table 4. Sediment discharges for the Red River of the North and selected tributaries near Fargo, North Dakota, during the 2010 spring high-flow event.

[MEP, Modified Einstein Procedure]

\begin{tabular}{|c|c|c|c|c|c|}
\hline \multirow{2}{*}{$\begin{array}{c}\text { Date } \\
\text { (month/day/year) }\end{array}$} & \multicolumn{5}{|c|}{ Discharge, in tons per day } \\
\hline & $\begin{array}{c}\text { Suspended } \\
\text { sediment }\end{array}$ & $\begin{array}{c}\text { Measured } \\
\text { bedload }\end{array}$ & $\begin{array}{c}\text { MEP } \\
\text { bedload }\end{array}$ & $\begin{array}{c}\text { Measured total } \\
\text { sediment }\end{array}$ & $\begin{array}{r}\text { MEP total } \\
\text { sediment }\end{array}$ \\
\hline \multicolumn{6}{|c|}{ Red River of the North near Christine (site 1) } \\
\hline $03 / 18 / 2010$ & 3,890 & 61 & 60 & 3,950 & 3,950 \\
\hline $03 / 20 / 2010$ & 3,690 & -- & -- & -- & -- \\
\hline $03 / 21 / 2010$ & 1,930 & -- & -- & -- & -- \\
\hline $03 / 22 / 2010$ & 2,060 & 1 & 80 & 2,060 & 2,140 \\
\hline $03 / 23 / 2010$ & 1,830 & -- & -- & -- & -- \\
\hline $03 / 24 / 2010$ & 1,770 & -- & -- & -- & -- \\
\hline $03 / 25 / 2010$ & 1,660 & 3 & 10 & 1,660 & 1,670 \\
\hline $03 / 26 / 2010$ & 1,740 & -- & -- & -- & -- \\
\hline $03 / 27 / 2010$ & 2,450 & -- & -- & -- & -- \\
\hline $03 / 29 / 2010$ & 1,480 & 1 & 50 & 1,480 & 1,530 \\
\hline 04/01/2010 & 1,060 & -- & -- & -- & -- \\
\hline 04/06/2010 & 1,130 & 3 & 20 & 1,130 & 1,150 \\
\hline Mean & 2,060 & 14 & 44 & 2,060 & 2,090 \\
\hline Standard deviation & 893 & 26 & 29 & 1,110 & 1,100 \\
\hline \multicolumn{6}{|c|}{ Red River of the North near Fargo (site 2) } \\
\hline $03 / 17 / 2010$ & 4,210 & 6 & 70 & 4,220 & 4,280 \\
\hline 03/19/2010 & 6,930 & -- & -- & -- & -- \\
\hline $03 / 21 / 2010$ & 6,840 & -- & -- & -- & -- \\
\hline 03/23/2010 & 5,200 & 2 & 140 & 5,200 & 5,340 \\
\hline $03 / 24 / 2010$ & 5,110 & -- & -- & -- & -- \\
\hline $03 / 25 / 2010$ & 3,460 & 1 & 120 & 3,460 & 3,580 \\
\hline 03/26/2010 & 6,110 & -- & -- & -- & -- \\
\hline 03/27/2010 & 4,040 & -- & -- & -- & -- \\
\hline $03 / 31 / 2010$ & 3,950 & 0 & 40 & 3,950 & 3,990 \\
\hline Mean & 5,090 & 2 & 93 & 4,210 & 4,300 \\
\hline Standard deviation & 1,290 & 3 & 46 & 733 & 752 \\
\hline \multicolumn{6}{|c|}{ Sheyenne River above Sheyenne River Diversion near Horace (site 3) } \\
\hline $03 / 20 / 2010$ & 4,420 & 1 & 230 & 4,420 & 4,650 \\
\hline $03 / 21 / 2010$ & -- & -- & -- & -- & -- \\
\hline $03 / 22 / 2010$ & 4,730 & -- & -- & -- & -- \\
\hline $03 / 23 / 2010$ & 9,140 & 1 & 860 & 9,140 & 10,000 \\
\hline $03 / 24 / 2010$ & 14,600 & & -- & -- & -- \\
\hline $03 / 25 / 2010$ & 12,000 & 3 & 600 & 12,000 & 12,600 \\
\hline $03 / 26 / 2010$ & 9,550 & -- & -- & -- & -- \\
\hline 03/27/2010 & 8,990 & -- & -- & -- & -- \\
\hline 03/29/2010 & 8,080 & 1 & 330 & 8,080 & 8,410 \\
\hline $03 / 31 / 2010$ & 8,340 & 4 & 340 & 8,340 & 8,680 \\
\hline $04 / 05 / 2010$ & 5,250 & 4 & 280 & 5,250 & 5,530 \\
\hline 04/07/2010 & 4,580 & 1 & 100 & 4,580 & 4,680 \\
\hline Mean & 8,150 & 2 & 391 & 7,400 & 7,790 \\
\hline Standard deviation & 3,280 & 1 & 179 & 2,950 & 3,110 \\
\hline
\end{tabular}


Table 4. Sediment discharges for the Red River of the North and selected tributaries near Fargo, North Dakota, during the 2010 spring high-flow event.-Continued

[MEP, Modified Einstein Procedure]

\begin{tabular}{|c|c|c|c|c|c|}
\hline \multirow{2}{*}{$\begin{array}{c}\text { Date } \\
\text { (month/day/year) }\end{array}$} & \multicolumn{5}{|c|}{ Discharge, in tons per day } \\
\hline & $\begin{array}{l}\text { Suspended } \\
\text { sediment }\end{array}$ & $\begin{array}{c}\text { Measured } \\
\text { bedload }\end{array}$ & $\begin{array}{c}\text { MEP } \\
\text { bedload }\end{array}$ & $\begin{array}{l}\text { Measured total } \\
\text { sediment }\end{array}$ & $\begin{array}{c}\text { MEP total } \\
\text { sediment }\end{array}$ \\
\hline \multicolumn{6}{|c|}{ Sheyenne River at Horace (site 4) } \\
\hline $03 / 24 / 2010$ & 3,410 & 1 & 500 & 3,410 & 3,910 \\
\hline $03 / 25 / 2010$ & 5,250 & 0 & 1,140 & 5,250 & 6,390 \\
\hline $03 / 26 / 2010$ & 4,510 & -- & -- & -- & -- \\
\hline $03 / 27 / 2010$ & 4,420 & 0 & 620 & 4,420 & 5,040 \\
\hline 03/29/2010 & 3,820 & 0 & 240 & 3,820 & 4,060 \\
\hline $03 / 31 / 2010$ & 3,700 & 0 & 470 & 3,700 & 4,170 \\
\hline $04 / 05 / 2010$ & 3,460 & 0 & 340 & 3,460 & 3,800 \\
\hline $04 / 07 / 2010$ & 2,650 & 4 & 170 & 2,650 & 2,820 \\
\hline Mean & 3,900 & 1 & 497 & 4,150 & 3,820 \\
\hline Standard deviation & 800 & 1 & 323 & 825 & 825 \\
\hline \multicolumn{6}{|c|}{ Maple River below Mapleton (site 5) } \\
\hline $03 / 19 / 2010$ & 4,840 & 1 & 3,420 & 4,840 & 8,260 \\
\hline $03 / 20 / 2010$ & 2,790 & -- & -- & -- & -- \\
\hline $03 / 21 / 2010$ & 2,040 & -- & -- & -- & -- \\
\hline $03 / 22 / 2010$ & 1,880 & 0 & 930 & 1,880 & 2,810 \\
\hline $03 / 23 / 2010$ & 2,040 & -- & -- & -- & -- \\
\hline $03 / 24 / 2010$ & 1,720 & -- & -- & -- & -- \\
\hline $03 / 26 / 2010$ & 1,430 & 5 & 230 & 1,440 & 1,660 \\
\hline $03 / 27 / 2010$ & 1,920 & -- & -- & -- & -- \\
\hline $03 / 30 / 2010$ & 1,260 & 5 & 70 & 1,270 & 1,330 \\
\hline $04 / 02 / 2010$ & 1,030 & 7 & 210 & 1,040 & 1,240 \\
\hline $04 / 06 / 2010$ & 796 & 3 & 22 & 800 & 818 \\
\hline Mean & 1,980 & 4 & 814 & 1,880 & 2,690 \\
\hline Standard deviation & 1,100 & 2 & 1,320 & 1,500 & 2,810 \\
\hline \multicolumn{6}{|c|}{ Wild Rice River at I-25 near St. Benedict (site 6) } \\
\hline $03 / 18 / 2010$ & 3,890 & 10 & 330 & 3,900 & 4,220 \\
\hline $03 / 20 / 2010$ & 4,020 & -- & -- & -- & -- \\
\hline $03 / 21 / 2010$ & 3,120 & -- & -- & -- & -- \\
\hline $03 / 22 / 2010$ & 3,480 & 1 & 740 & 3,480 & 4,220 \\
\hline $03 / 23 / 2010$ & 2,770 & -- & -- & -- & -- \\
\hline $03 / 24 / 2010$ & 3,040 & -- & -- & -- & -- \\
\hline $03 / 25 / 2010$ & 2,840 & 0 & 100 & 2,840 & 2,940 \\
\hline $03 / 26 / 2010$ & 2,860 & -- & -- & -- & -- \\
\hline $03 / 27 / 2010$ & 2,970 & -- & -- & -- & -- \\
\hline $03 / 30 / 2010$ & 2,530 & 0 & 190 & 2,530 & 2,720 \\
\hline $04 / 01 / 2010$ & 2,070 & 1 & 120 & 2,070 & 2,190 \\
\hline Mean & 3,050 & 3 & 296 & 2,960 & 3,260 \\
\hline Standard deviation & 568 & 4 & 264 & 732 & 920 \\
\hline
\end{tabular}




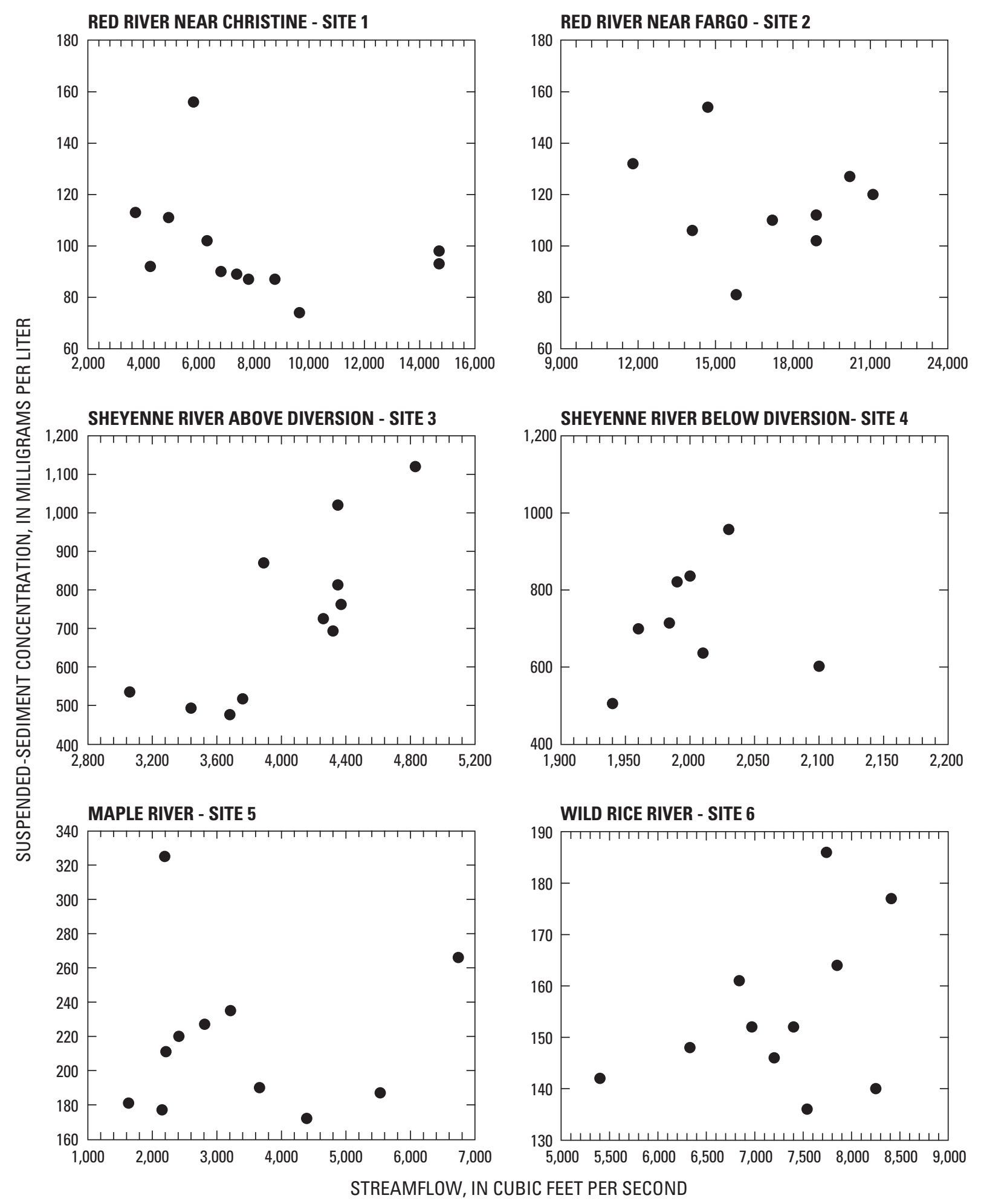

Figure 4. Suspended-sediment concentration and streamflow relations in the Red River of the North and selected tributaries near Fargo, North Dakota, during the 2010 spring high-flow event.

810 tons/day (MEP bedload discharge is larger than physically sampled bedload discharge by a factor of 204) at the Maple River (table 4). These results were similar to several other studies that found Einstein's bedload function was unable to accurately predict bedload discharge in certain rivers. For example, Kiat and others (2007) compared bedload samples for 122 sets of data for sandbed rivers in Malaysia with Einstein's bedload equation and determined that it overestimated bedload discharge when compared to the measured values. Pires and Ribeiro (1988) also evaluated the Einstein method 


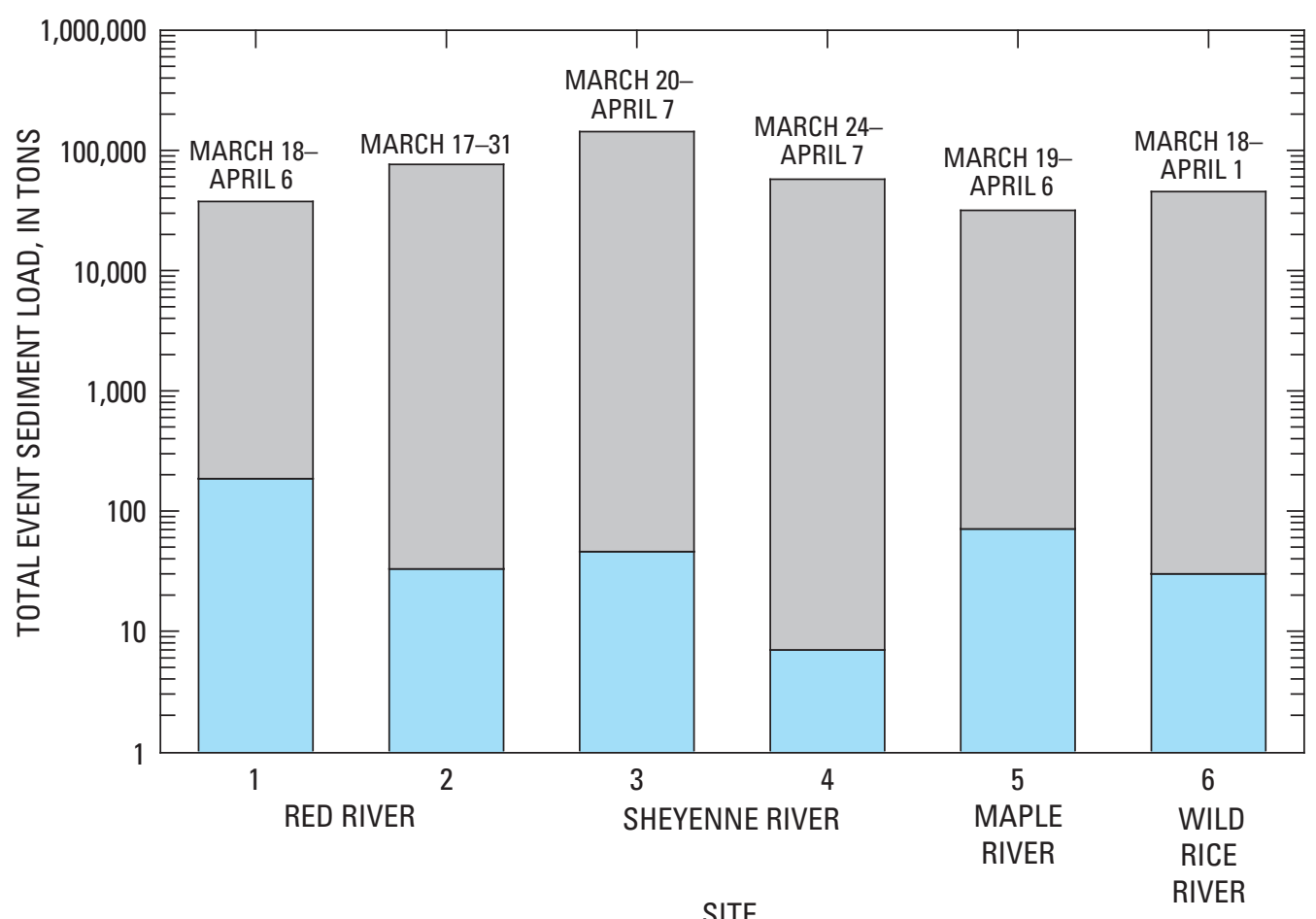

EXPLANATION

MARCH 17-31 Load calculation period

Suspended-sediment load

Bedload

Figure 5. Estimated total event sediment loads in the Red River of the North and selected tributaries near Fargo, North Dakota, during the 2010 spring high-flow event.

of estimating bedload discharge in a backwater river located in Brazil and found that the Einstein method of using tractive forces overestimated bedload transport. Einstein's bedloaddischarge function is based upon statistical probabilities that particles of a given size move in a uniform flow over a constant slope, which may not have occurred in the Red River and its tributaries during the study period.

\section{Particle-Size Distribution}

Particle-size distribution for the suspended sediment, bedload, and bed material of a stream is important in the design of engineering projects because it is used in numerical modeling of sediment discharges and provides insight on the stability of the stream. Samples collected during the 2010 high-flow event were analyzed for particle-size distribution when enough material was collected.

For the majority of all samples collected during the 2010 spring high-flow event, with the exception of both of the Sheyenne River sites, more than 90 percent of the measured suspended sediment was composed of fine-grained particles (less than $0.062 \mathrm{~mm}$ ) (table 2). Samples from the Sheyenne
River above Diversion had 9 to 18 percent of the suspended sediment with particle sizes greater than $0.062 \mathrm{~mm}$ up to $0.125 \mathrm{~mm}$ and 4 to 14 percent greater than the $0.125-\mathrm{mm}$ particle size. Samples from the Sheyenne River below Diversion had 9 to 17 percent of the suspended sediment with particle sizes greater than $0.062 \mathrm{~mm}$ up to $0.125 \mathrm{~mm}$ and 6 to 12 percent greater than the $0.125-\mathrm{mm}$ particle size (table 2 ).

Particle-size analyses from bedload samples collected during the 2010 spring high-flow event indicated material in the Red River near Christine, Red River near Fargo, and Maple River was coarser than material in the Sheyenne River above Diversion, Sheyenne River below Diversion, and the Wild Rice River (table 6). For all sites, particle sizes did not exceed $16 \mathrm{~mm}$. The bedload in the Maple River had particle sizes mostly (62 percent) in the range of $0.5 \mathrm{~mm}$ to $4 \mathrm{~mm}$, and the Red River near Christine and Red River near Fargo had particle sizes mostly in the range of $0.25 \mathrm{~mm}$ to $2 \mathrm{~mm}$ range (66 and 69 percent, respectively). The bedload in the Sheyenne River above Diversion, Sheyenne River below Diversion, and the Wild Rice River had particle sizes mostly in the range of $0.125 \mathrm{~mm}$ to $0.5 \mathrm{~mm}(53,56$, and 41 percent, respectively) (table 6).

The bed material in samples collected during the 2010 spring high-flow event demonstrated a different areal 
RED RIVER NEAR CHRISTINE - SITE

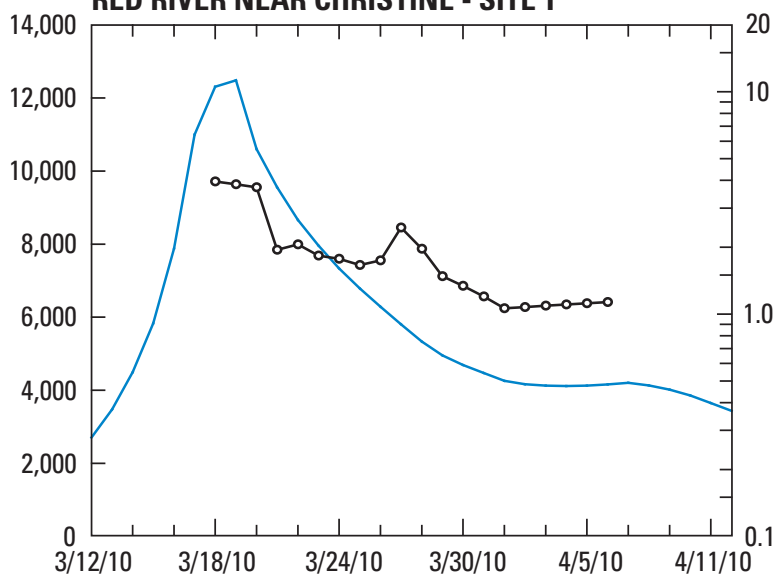

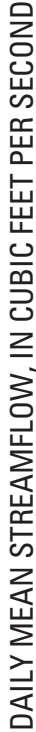

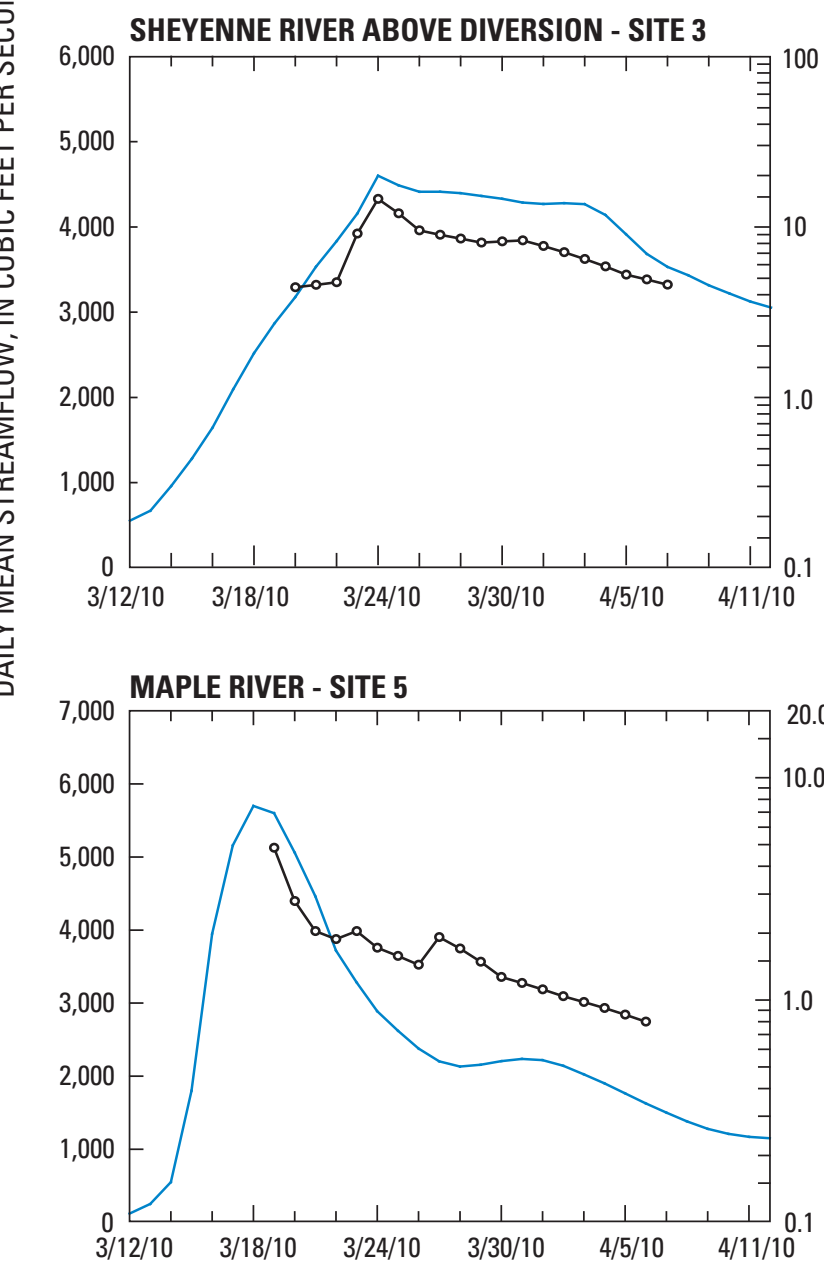

RED RIVER NEAR FARGO - SITE 2
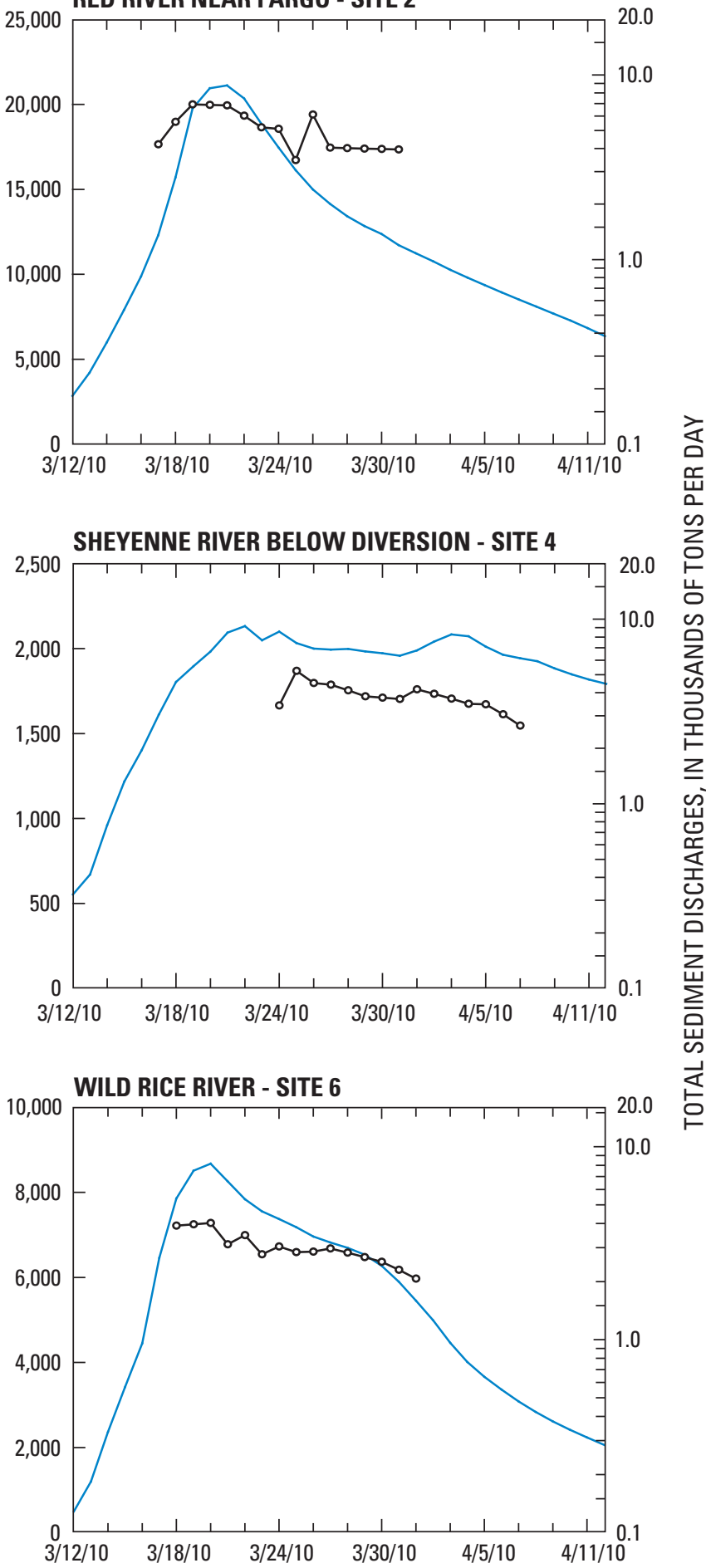

EXPLANATION

- Daily mean streamflow

$\multimap-$ Measured suspended-sediment concentration

Figure 6. Time series of streamflow and total sediment discharges for the Red River of the North and selected tributaries near Fargo, North Dakota, during the 2010 spring high-flow event. 
Table 5. Input data for the Modified Einstein Procedure for the Red River of the North and selected tributaries near Fargo, North Dakota, during the 2010 spring high-flow event.

[ft/s, foot per second; ft, feet, ${ }^{\circ} \mathrm{C}$, degree Celsius]

\begin{tabular}{|c|c|c|c|c|}
\hline $\begin{array}{c}\text { Date } \\
\text { (month/day/ } \\
\text { year) }\end{array}$ & $\begin{array}{c}\text { Velocity } \\
\text { (ft/s) }\end{array}$ & $\begin{array}{c}\text { Width } \\
\text { (ft) }\end{array}$ & $\begin{array}{l}\text { Maximum } \\
\text { depth (ft) }\end{array}$ & $\begin{array}{c}\text { Water } \\
\text { temperature } \\
\left({ }^{\circ} \mathrm{C}\right)\end{array}$ \\
\hline \multicolumn{5}{|c|}{ Red River of the North near Christine (site 1) } \\
\hline 03/18/2010 & 2.5 & 220 & 31.5 & 33.1 \\
\hline $03 / 22 / 2010$ & 2.5 & 200 & 28.7 & 35.2 \\
\hline $03 / 25 / 2010$ & 2.2 & 190 & 24.4 & 39.4 \\
\hline $03 / 29 / 2010$ & 2.7 & 180 & 19.8 & 39.7 \\
\hline $04 / 06 / 2010$ & 1.9 & 150 & 17.9 & 51.0 \\
\hline \multicolumn{5}{|c|}{ Red River of the North near Fargo (site 2) } \\
\hline $03 / 17 / 2010$ & 1.7 & 440 & 29.0 & 32.0 \\
\hline $03 / 23 / 2010$ & 2.3 & 450 & 32.0 & 35.1 \\
\hline $03 / 25 / 2010$ & 2.1 & 450 & 33.0 & 36.9 \\
\hline $03 / 31 / 2010$ & 1.7 & 440 & 30.0 & 45.5 \\
\hline \multicolumn{5}{|c|}{ Sheyenne River above Sheyenne River Diversion near Horace (site 3) } \\
\hline $03 / 20 / 2010$ & 3.0 & 81 & 25.0 & 32.2 \\
\hline 03/23/2010 & 2.4 & 90 & 26.0 & 32.5 \\
\hline $03 / 25 / 2010$ & 2.5 & 81 & 26.0 & 36.1 \\
\hline $03 / 29 / 2010$ & 2.5 & 81 & 26.0 & 40.1 \\
\hline $03 / 31 / 2010$ & 2.5 & 81 & 26.0 & 42.8 \\
\hline 04/05/2010 & 2.4 & 81 & 26.0 & 44.8 \\
\hline 04/07/2010 & 2.6 & 81 & 25.0 & 44.6 \\
\hline \multicolumn{5}{|c|}{ Sheyenne River at Horace (site 4) } \\
\hline $03 / 24 / 2010$ & 2.5 & 110 & 17.0 & 33.6 \\
\hline $03 / 25 / 2010$ & 2.1 & 108 & 16.0 & 34.5 \\
\hline $03 / 27 / 2010$ & 2.1 & 110 & 16.0 & 36.1 \\
\hline 03/29/2010 & 2.4 & 108 & 18.0 & 39.2 \\
\hline $03 / 31 / 2010$ & 1.5 & 100 & 18.0 & 43.3 \\
\hline $04 / 05 / 2010$ & 1.5 & 100 & 17.7 & 45.5 \\
\hline $04 / 07 / 2010$ & 1.4 & 100 & 17.0 & 45.5 \\
\hline
\end{tabular}

\begin{tabular}{lllll}
\hline \multicolumn{5}{c}{ Maple River below Mapleton (site 5) } \\
\hline $03 / 19 / 2010$ & 4.2 & 170 & 17.7 & 33.6 \\
$03 / 22 / 2010$ & 3.0 & 140 & 16.2 & 36.7 \\
$03 / 26 / 2010$ & 2.2 & 140 & 14.0 & 33.1 \\
$03 / 30 / 2010$ & 2.2 & 130 & 12.7 & 43.7 \\
$04 / 02 / 2010$ & 2.2 & 120 & 13.1 & 43.5 \\
$04 / 06 / 2010$ & 1.8 & 100 & 11.5 & 45.0 \\
\hline
\end{tabular}

Wild Rice River at I-25 near St. Benedict (site 6)

\begin{tabular}{lllll}
\hline $03 / 18 / 2010$ & 2.6 & 220 & 26.5 & 33.4 \\
$03 / 22 / 2010$ & 1.6 & 200 & 27.3 & 34.7 \\
$03 / 25 / 2010$ & 2.5 & 200 & 27.0 & 39.0 \\
$03 / 30 / 2010$ & 2.3 & 220 & 24.0 & 41.9 \\
$04 / 01 / 2010$ & 2.0 & 220 & 23.4 & 49.3 \\
\hline
\end{tabular}

distribution of particle sizes among sites when compared to bedload, with the coarsest material found at the Red River near Christine, whereas the finest material was found at the Sheyenne River below Diversion (table 7). For the Red River near Christine, nearly 40 percent of the bed material ranged in size between 2 and $16 \mathrm{~mm}$, whereas only 3 percent of the bed material at the Sheyenne River below Diversion was in this same size class. The Wild Rice River also had relatively coarser bed material when compared to the Maple River, Sheyenne River above Diversion, and Sheyenne River below Diversion (30 percent in the 2 to $16 \mathrm{~mm}$ size class at the Wild Rice River compared to 8 percent and 3 percent at Sheyenne River above Diversion and Sheyenne River below Diversion, respectively) but had a similar distribution of particle sizes to the Red River near Fargo (30 percent compared to 21 percent, respectively). For the Sheyenne River above Diversion and Sheyenne River below Diversion, bed material particle sizes were predominantly in the lower size classes, with 83 percent and 80 percent, respectively in the 0.062 to $2 \mathrm{~mm}$ size classes. Similar to the Sheyenne River sites, the Maple River also demonstrated a majority (76 percent) of its bed material in the lower size classes between 0.062 and $2 \mathrm{~mm}$ (table 7).

\section{Point Samples of Suspended Sediment}

Samples collected at discrete vertical depths above the channel thalweg (point samples) at six sites on the Red River and its tributaries near the Fargo-Moorhead metropolitan area during the 2010 spring high-flow event showed that the vertical distribution of SSC varied among sites and throughout the event at each site (fig. 7 and table 8). Differences in SSC among point samples collected at various depths during the same sample interval ranged from $6 \mathrm{mg} / \mathrm{L}$ at Sheyenne River above Diversion (March 20) to $174 \mathrm{mg} / \mathrm{L}$ at Maple River (March 23). SSC at the Red River near Christine alternated back and forth during the recession in streamflow from being the greatest in the bottom sample to the greatest in the top sample of the water column with no discernable pattern throughout the event (fig. 7). The Red River near Fargo had the greatest SSC near the top of the water column in the first two samples collected on March 23 and 26 and the greatest SSC near the bottom of the water column in the third sample collected on March 31. The Sheyenne River above Diversion had the greatest concentrations in the sample from the middle of the stream throughout the rise, peak, and fall in streamflow, except for one sample during the streamflow recession where the greatest SSC was found in the bottom sample. In comparison, the Sheyenne River below Diversion showed mostly greater SSC in the top or bottom samples, with one sample that had a slightly greater SSC in the middle sample collected later in the streamflow recession (fig. 7). Samples from the Maple River showed the greatest SSC in the top and bottom samples with one exception on March 30. A sample from the Maple River also had the greatest difference in SSC among 
Table 6. Sieve diameters and mass of bedload samples for the Red River of the North and selected tributaries near Fargo, North Dakota, during the 2010 spring high-flow event.

[mm, millimeter]

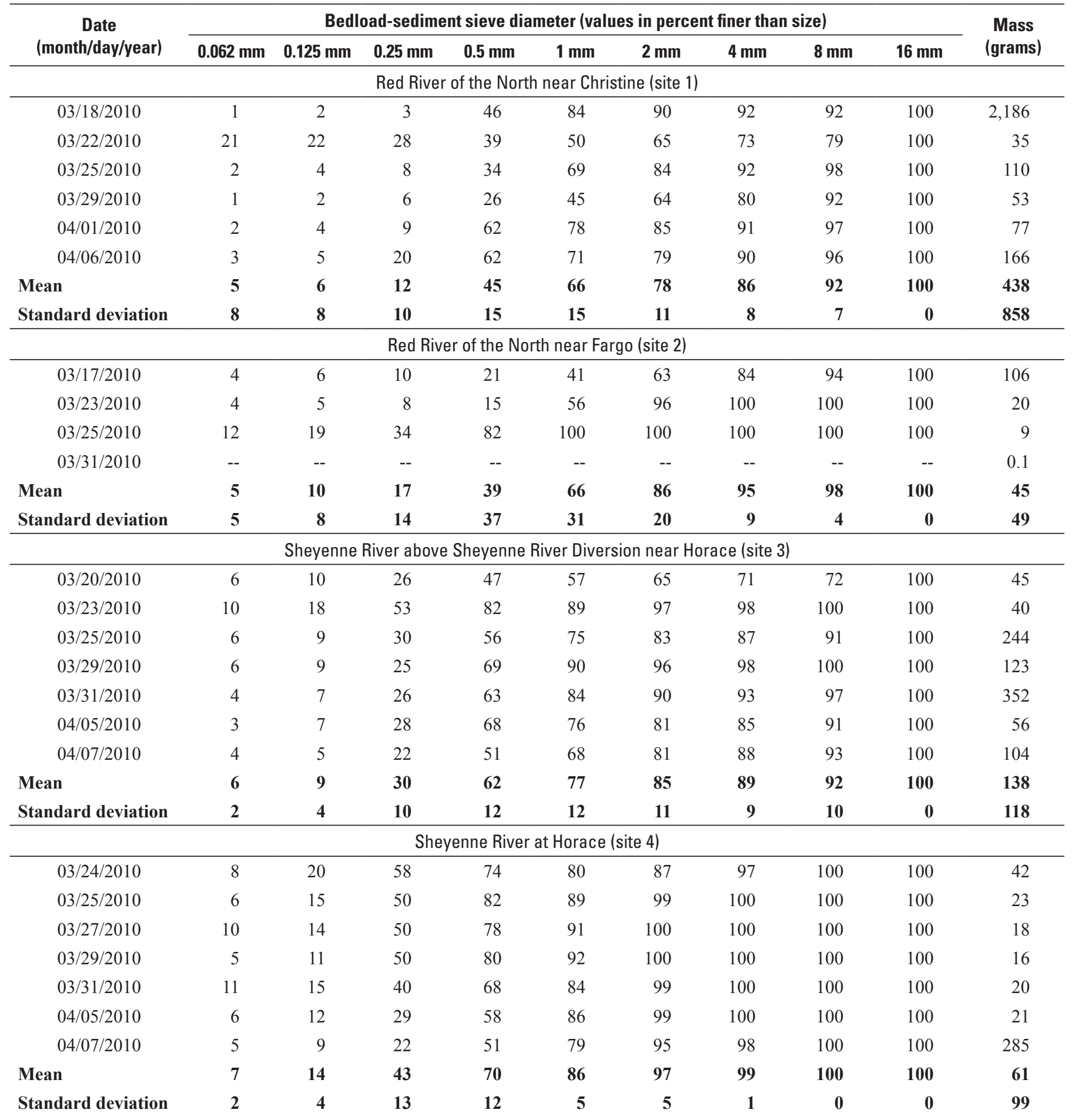


Table 6. Sieve diameters and mass of bedload samples for the Red River of the North and selected tributaries near Fargo, North Dakota, during the 2010 spring high-flow event.-Continued

[mm, millimeter]

\begin{tabular}{|c|c|c|c|c|c|c|c|c|c|c|}
\hline \multirow{2}{*}{$\begin{array}{c}\text { Date } \\
\text { (month/day/year) }\end{array}$} & \multicolumn{9}{|c|}{ Bedload-sediment sieve diameter (values in percent finer than size) } & \multirow{2}{*}{$\begin{array}{c}\text { Mass } \\
\text { (grams) }\end{array}$} \\
\hline & $0.062 \mathrm{~mm}$ & $0.125 \mathrm{~mm}$ & $0.25 \mathrm{~mm}$ & $0.5 \mathrm{~mm}$ & $1 \mathrm{~mm}$ & $2 \mathrm{~mm}$ & $4 \mathrm{~mm}$ & $8 \mathrm{~mm}$ & $16 \mathrm{~mm}$ & \\
\hline \multicolumn{11}{|c|}{ Maple River below Mapleton (site 5) } \\
\hline $03 / 19 / 2010$ & 7 & 9 & 15 & 30 & 54 & 76 & 86 & 95 & 100 & 68 \\
\hline $03 / 22 / 2010$ & 10 & 19 & 32 & 59 & 84 & 100 & 100 & 100 & 100 & 10 \\
\hline $03 / 26 / 2010$ & 4 & 5 & 9 & 17 & 35 & 73 & 98 & 99 & 100 & 259 \\
\hline 03/30/2010 & 3 & 5 & 9 & 26 & 52 & 77 & 96 & 100 & 100 & 292 \\
\hline $04 / 02 / 2010$ & 4 & 7 & 11 & 36 & 63 & 85 & 96 & 99 & 100 & 140 \\
\hline $04 / 06 / 2010$ & 4 & 6 & 11 & 26 & 50 & 72 & 88 & 96 & 100 & 253 \\
\hline Mean & 5 & 8 & 14 & 32 & 56 & 80 & 94 & 98 & 100 & 170 \\
\hline Standard deviation & 3 & 5 & 9 & 14 & 16 & 11 & 6 & 2 & $\mathbf{0}$ & 115 \\
\hline \multicolumn{11}{|c|}{ Wild Rice River at I-25 near St. Benedict (site 6) } \\
\hline $03 / 18 / 2010$ & 4 & 6 & 10 & 18 & 33 & 54 & 84 & 99 & 100 & 361 \\
\hline $03 / 22 / 2010$ & 33 & 41 & 57 & 83 & 99 & 99 & 99 & 100 & 100 & 54 \\
\hline $03 / 25 / 2010$ & 15 & 30 & 60 & 90 & 100 & 100 & 100 & 100 & 100 & 2 \\
\hline $03 / 30 / 2010$ & 13 & 37 & 63 & 100 & 100 & 100 & 100 & 100 & 100 & 3 \\
\hline $04 / 01 / 2010$ & 21 & 27 & 38 & 54 & 75 & 87 & 89 & 89 & 100 & 52 \\
\hline Mean & 17 & 28 & 46 & 69 & 81 & 88 & 94 & 98 & 100 & 79 \\
\hline Standard deviation & 11 & 14 & 22 & 33 & 29 & 20 & 7 & 5 & $\mathbf{0}$ & 151 \\
\hline
\end{tabular}

the samples collected at three depths, ranging in concentration from $54 \mathrm{mg} / \mathrm{L}$ in the middle sample to $228 \mathrm{mg} / \mathrm{L}$ in the bottom sample. The large difference in concentration may have been caused by turbulent flow during the sampling, resulting in an unusual vertical distribution in suspended sediment, or the sampler used to collect the middle sample did not function properly and did not fully collect the sample. The SSC at the Wild Rice River transitioned from being the greatest in the top sample to the greatest in the middle sample and then the greatest in the bottom sample as the streamflow receded (fig. 7 and table 8).

For most of the sites sampled, with the exception of the Sheyenne River above Diversion and Sheyenne River below Diversion, there was not enough material suspended in the water column at the sampling points to conduct a full particlesize analysis (table 8). The particle sizes from sieve analyses for the Red River near Christine, Red River near Fargo, Maple River, and Wild Rice River indicated that 82 to 99 percent of the suspended sediment was less than $0.062 \mathrm{~mm}$ (fine-grained particles) and did not vary substantially with depth. The Sheyenne River above Diversion had SSC with 11 to 25 percent of the particles greater than $0.062 \mathrm{~mm}$ and 2 to 11 percent of the particles greater than $0.125 \mathrm{~mm}$ and did not show substantial differences in size distribution at different depths (table 8). Most samples collected at the Sheyenne River below Diversion had SSC that had particles sizes greater than $0.062 \mathrm{~mm}$ ( 7 to 24 percent) and few with particle sizes greater than $0.125 \mathrm{~mm}$ ( 1 to 8 percent).

\section{Quality Assurance}

Quality-assurance samples were collected for SSC and bedload during the 2010 spring high-flow event to estimate the variability in the laboratory analysis and reproducibility in the collection of the samples. Eight replicate samples were collected and analyzed for SSC and three bedload-replicate samples were collected and analyzed for bedload mass (table 9). The analytical variability of SSC samples was minimal with differences less than 3 percent for all but one sample from Sheyenne River above Diversion that had a 39.1 percent difference. Analytical variability was relatively large for bedload samples collected during the 2010 spring high-flow event. Bedload-replicate samples differed from each other by 80.0 to 151.9 percent. This large variation may be attributed to a combination of factors that make it difficult to accurately sample bedload using current methods. According to Edwards and Glysson (1999), placing any device, such as a bedload sampler, on or near the streambed may disturb the flow pattern of the stream and, consequently, the rate of bedload movement. Moreover, the rate of bedload movement and the velocity of water close to the streambed vary considerably both spatially and temporally. Because of this, any sample obtained at a given point may be extremely difficult to repeat because bed particles move intermittently according to the velocity and supply of sediment available at the specific time and point where the sample was collected. 
Table 7. Sieve diameters of bed-material samples for the Red River of the North and selected tributaries near Fargo, North Dakota, during the 2010 spring high-flow event.

[mm, millimeter; --, no value]

\begin{tabular}{|c|c|c|c|c|c|c|c|c|c|}
\hline \multirow{2}{*}{$\begin{array}{c}\text { Date } \\
\text { (month/day/year) }\end{array}$} & \multicolumn{9}{|c|}{ Bed material sieve diameter (values in percent finer than size) } \\
\hline & $0.062 \mathrm{~mm}$ & $0.125 \mathrm{~mm}$ & $0.25 \mathrm{~mm}$ & $0.5 \mathrm{~mm}$ & $1 \mathrm{~mm}$ & $2 \mathrm{~mm}$ & $4 \mathrm{~mm}$ & $8 \mathrm{~mm}$ & $16 \mathrm{~mm}$ \\
\hline \multicolumn{10}{|c|}{ Red River of the North near Christine (site 1) } \\
\hline $03 / 18 / 2010$ & 1 & 1 & 2 & 40 & 66 & 71 & 75 & 81 & 100 \\
\hline $03 / 20 / 2010$ & 0 & 1 & 1 & 5 & 13 & 23 & 31 & 44 & 100 \\
\hline $03 / 21 / 2010$ & 8 & 12 & 16 & 30 & 40 & 47 & 55 & 70 & 100 \\
\hline $03 / 22 / 2010$ & 8 & 12 & 17 & 24 & 36 & 69 & 94 & 100 & 100 \\
\hline $03 / 23 / 2010$ & 2 & 4 & 6 & 23 & 40 & 48 & 58 & 69 & 100 \\
\hline $03 / 24 / 2010$ & 4 & 6 & 11 & 20 & 33 & 48 & 64 & 82 & 100 \\
\hline $03 / 25 / 2010$ & 3 & 3 & 6 & 14 & 44 & 74 & 82 & 87 & 100 \\
\hline $03 / 26 / 2010$ & 1 & 2 & 5 & 18 & 42 & 57 & 66 & 75 & 100 \\
\hline $03 / 27 / 2010$ & 11 & 15 & 19 & 42 & 62 & 84 & 96 & 100 & 100 \\
\hline $03 / 29 / 2010$ & 1 & 2 & 4 & 20 & 53 & 68 & 74 & 81 & 100 \\
\hline $04 / 01 / 2010$ & 2 & 4 & 11 & 39 & 60 & 69 & 73 & 84 & 100 \\
\hline $04 / 06 / 2010$ & 1 & 2 & 5 & 33 & 57 & 67 & 73 & 86 & 100 \\
\hline Mean & 4 & 5 & 9 & 26 & 45 & 60 & 70 & 80 & 100 \\
\hline Standard deviation & 3 & 5 & 6 & 11 & 14 & 16 & 17 & 14 & $\mathbf{0}$ \\
\hline \multicolumn{10}{|c|}{ Red River of the North near Fargo (site 2) } \\
\hline $03 / 17 / 2010$ & 3 & 5 & 11 & 21 & 45 & 73 & 90 & 98 & 100 \\
\hline $03 / 19 / 2010$ & 3 & 5 & 8 & 18 & 47 & 76 & 93 & 99 & 100 \\
\hline $03 / 21 / 2010$ & 10 & 15 & 24 & 39 & 61 & 87 & 98 & 100 & 100 \\
\hline $03 / 23 / 2010$ & 6 & 9 & 14 & 24 & 42 & 71 & 95 & 99 & 100 \\
\hline $03 / 24 / 2010$ & 2 & 2 & 3 & 8 & 40 & 81 & 96 & 100 & 100 \\
\hline $03 / 25 / 2010$ & 2 & 3 & 5 & 22 & 34 & 42 & 52 & 68 & 100 \\
\hline $03 / 26 / 2010$ & 3 & 5 & 13 & 45 & 75 & 93 & 99 & 100 & 100 \\
\hline $03 / 27 / 2010$ & 26 & 35 & 44 & 58 & 81 & 97 & 100 & 100 & 100 \\
\hline $03 / 31 / 2010$ & 22 & 34 & 51 & 61 & 76 & 91 & 99 & 99 & 100 \\
\hline Mean & 9 & 13 & 19 & 33 & 56 & 79 & 91 & 96 & 100 \\
\hline Standard deviation & 9 & 13 & 17 & 19 & 18 & 17 & 15 & 10 & $\mathbf{0}$ \\
\hline \multicolumn{10}{|c|}{ Sheyenne River above Sheyenne River Diversion near Horace (site 3) } \\
\hline $03 / 20 / 2010$ & 4 & 22 & 85 & 98 & 100 & 100 & 100 & 100 & 100 \\
\hline $03 / 21 / 2010$ & 9 & 35 & 85 & 95 & 97 & 98 & 99 & 99 & 100 \\
\hline $03 / 22 / 2010$ & 45 & 52 & 63 & 76 & 93 & 98 & 100 & 100 & 100 \\
\hline $03 / 23 / 2010$ & 17 & 33 & 83 & 100 & 100 & 100 & 100 & 100 & 100 \\
\hline $03 / 24 / 2010$ & 3 & 13 & 42 & 50 & 62 & 81 & 91 & 97 & 100 \\
\hline $03 / 25 / 2010$ & 5 & 15 & 51 & 79 & 97 & 98 & 98 & 98 & 100 \\
\hline $03 / 26 / 2010$ & 8 & 13 & 34 & 44 & 62 & 84 & 89 & 100 & 100 \\
\hline $03 / 27 / 2010$ & 4 & 9 & 32 & 66 & 89 & 96 & 98 & 100 & 100 \\
\hline $03 / 29 / 2010$ & 3 & 6 & 27 & 53 & 78 & 95 & 99 & 100 & 100 \\
\hline $03 / 31 / 2010$ & 3 & 9 & 33 & 60 & 82 & 92 & 96 & 99 & 100 \\
\hline $04 / 05 / 2010$ & 5 & 10 & 30 & 60 & 90 & 100 & 100 & 100 & 100 \\
\hline $04 / 07 / 2010$ & 1 & 2 & 7 & 16 & 38 & 65 & 79 & 87 & 100 \\
\hline Mean & 9 & 18 & 48 & 66 & 81 & 92 & 96 & 98 & 100 \\
\hline Standard deviation & 12 & 15 & 26 & 25 & 19 & 11 & 6 & 4 & $\mathbf{0}$ \\
\hline
\end{tabular}


Table 7. Sieve diameters of bed-material samples for the Red River of the North and selected tributaries near Fargo, North Dakota, during the 2010 spring high-flow event.-Continued

[mm, millimeter; --, no value]

\begin{tabular}{|c|c|c|c|c|c|c|c|c|c|}
\hline \multirow{2}{*}{$\begin{array}{c}\text { Date } \\
\text { (month/day/year) }\end{array}$} & \multicolumn{9}{|c|}{ Bed material sieve diameter (values in percent finer than size) } \\
\hline & $0.062 \mathrm{~mm}$ & $0.125 \mathrm{~mm}$ & $0.25 \mathrm{~mm}$ & $0.5 \mathrm{~mm}$ & $1 \mathrm{~mm}$ & $2 \mathrm{~mm}$ & $4 \mathrm{~mm}$ & $8 \mathrm{~mm}$ & $16 \mathrm{~mm}$ \\
\hline \multicolumn{10}{|c|}{ Sheyenne River at Horace (site 4) } \\
\hline $03 / 24 / 2010$ & 10 & 41 & 95 & 99 & 100 & 100 & 100 & 100 & 100 \\
\hline $03 / 25 / 2010$ & 19 & 65 & 90 & 95 & 98 & 100 & 100 & 100 & 100 \\
\hline $03 / 26 / 2010$ & 14 & 51 & 85 & 92 & 98 & 100 & 100 & 100 & 100 \\
\hline $03 / 27 / 2010$ & 17 & 40 & 79 & 91 & 98 & 100 & 100 & 100 & 100 \\
\hline 03/29/2010 & 27 & 36 & 82 & 100 & 100 & 100 & 100 & 100 & 100 \\
\hline $03 / 31 / 2010$ & 31 & 64 & 89 & 94 & 98 & 100 & 100 & 100 & 100 \\
\hline $04 / 05 / 2010$ & 4 & 25 & 56 & 61 & 68 & 77 & 92 & 99 & 100 \\
\hline 04/07/2010 & 11 & 53 & 96 & 98 & 99 & 99 & 100 & 100 & 100 \\
\hline Mean & 17 & 47 & 84 & 91 & 95 & 97 & 99 & 100 & 100 \\
\hline Standard deviation & 9 & 14 & 13 & 13 & 11 & 8 & 3 & $\mathbf{0}$ & $\mathbf{0}$ \\
\hline \multicolumn{10}{|c|}{ Maple River below Mapleton (site 5) } \\
\hline $03 / 19 / 2010$ & 15 & 25 & 37 & 48 & 61 & 79 & 90 & 99 & 100 \\
\hline $03 / 20 / 2010$ & 8 & 20 & 24 & 34 & 40 & 58 & 84 & 100 & 100 \\
\hline $03 / 21 / 2010$ & 15 & 21 & 27 & 33 & 39 & 48 & 53 & 53 & 100 \\
\hline $03 / 22 / 2010$ & 18 & 31 & 55 & 74 & 87 & 99 & 100 & 100 & 100 \\
\hline $03 / 23 / 2010$ & 5 & 8 & 15 & 36 & 74 & 93 & 98 & 100 & 100 \\
\hline $03 / 24 / 2010$ & 5 & 8 & 15 & 37 & 71 & 94 & 99 & 100 & 100 \\
\hline $03 / 26 / 2010$ & 0 & 0 & 17 & 33 & 67 & 83 & 83 & 100 & 100 \\
\hline 03/27/2010 & 6 & 10 & 19 & 42 & 74 & 95 & 100 & 100 & 100 \\
\hline $03 / 30 / 2010$ & 4 & 6 & 12 & 35 & 67 & 90 & 98 & 100 & 100 \\
\hline $04 / 02 / 2010$ & 5 & 9 & 16 & 44 & 76 & 93 & 99 & 100 & 100 \\
\hline 04/06/2010 & 5 & 9 & 16 & 50 & 80 & 95 & 99 & 100 & 100 \\
\hline Mean & 8 & 13 & 23 & 42 & 67 & 84 & 91 & 96 & 100 \\
\hline Standard deviation & 6 & 9 & 13 & 12 & 15 & 17 & 14 & 14 & $\mathbf{0}$ \\
\hline \multicolumn{10}{|c|}{ Wild Rice River at I-25 near St. Benedict (site 6) } \\
\hline $03 / 18 / 2010$ & 5 & 8 & 12 & 15 & 20 & 54 & 80 & 98 & 100 \\
\hline 03/20/2010 & 6 & 10 & 18 & 35 & 56 & 74 & 86 & 93 & 100 \\
\hline $03 / 21 / 2010$ & 4 & 7 & 12 & 25 & 49 & 77 & 92 & 96 & 100 \\
\hline $03 / 22 / 2010$ & 18 & 24 & 43 & 65 & 77 & 91 & 96 & 97 & 100 \\
\hline $03 / 23 / 2010$ & 11 & 15 & 21 & 29 & 42 & 59 & 78 & 94 & 100 \\
\hline $03 / 24 / 2010$ & 13 & 25 & 63 & 75 & 100 & 100 & 100 & 100 & 100 \\
\hline $03 / 25 / 2010$ & 6 & 8 & 12 & 18 & 27 & 42 & 72 & 90 & 100 \\
\hline $03 / 26 / 2010$ & 8 & 9 & 13 & 20 & 30 & 47 & 71 & 91 & 100 \\
\hline $03 / 27 / 2010$ & 12 & 19 & 33 & 52 & 64 & 80 & 96 & 98 & 100 \\
\hline 03/30/2010 & 13 & 18 & 29 & 43 & 60 & 84 & 98 & 100 & 100 \\
\hline 04/01/2010 & 17 & 23 & 29 & 38 & 51 & 68 & 81 & 91 & 100 \\
\hline Mean & 10 & 15 & 26 & 38 & 52 & 70 & 86 & 95 & 100 \\
\hline Standard deviation & 5 & 7 & 16 & 20 & 23 & 18 & 11 & 4 & $\mathbf{0}$ \\
\hline
\end{tabular}


Table 8. Fall diameter, sieve diameter, and suspended-sediment concentration for samples collected at discrete vertical depths during the 2010 spring high-flow event at the Red River of the North and selected tributaries near Fargo, North Dakota.

[ft, feet; mm, millimeter; mg/L, milligrams per liter; IM, insufficient data for analysis; --, no value]

\begin{tabular}{|c|c|c|c|c|c|c|c|}
\hline \multirow{2}{*}{$\begin{array}{c}\text { Date } \\
\text { (month/day/year) }\end{array}$} & \multirow{2}{*}{$\begin{array}{l}\text { Sampling } \\
\text { depth (ft) }\end{array}$} & \multirow{2}{*}{$\begin{array}{l}\text { Suspended- } \\
\text { sediment con- } \\
\text { centration (mg/L) }\end{array}$} & \multicolumn{4}{|c|}{$\begin{array}{l}\text { Suspended-sediment fall diameter (values in percent finer } \\
\text { than size) }\end{array}$} & \multirow{2}{*}{$\begin{array}{l}\text { Percent finer than sus- } \\
\text { pended sediment sieve } \\
\text { diameter of } 0.062 \mathrm{~mm}\end{array}$} \\
\hline & & & $0.062 \mathrm{~mm}$ & $0.125 \mathrm{~mm}$ & $0.250 \mathrm{~mm}$ & $0.500 \mathrm{~mm}$ & \\
\hline \multicolumn{8}{|c|}{ Red River of the North near Christine (site 1) } \\
\hline \multirow[t]{3}{*}{$03 / 20 / 2010$} & 5 & 99 & IM & IM & IM & IM & 89 \\
\hline & 15 & 107 & IM & IM & IM & IM & 86 \\
\hline & 25 & 136 & IM & IM & $\mathrm{IM}$ & IM & 77 \\
\hline \multirow[t]{3}{*}{$03 / 23 / 2010$} & 5 & 101 & IM & IM & IM & IM & 88 \\
\hline & 14 & 101 & IM & $\mathrm{IM}$ & $\mathrm{IM}$ & IM & 88 \\
\hline & 23 & 94 & IM & IM & IM & IM & 91 \\
\hline \multirow[t]{3}{*}{$03 / 26 / 2010$} & 4 & 132 & IM & IM & IM & IM & 93 \\
\hline & 12 & 117 & IM & IM & IM & IM & 97 \\
\hline & 20 & 118 & IM & IM & IM & IM & 95 \\
\hline \multirow[t]{3}{*}{ 03/29/2010 } & 3 & 124 & IM & IM & IM & IM & 96 \\
\hline & 10 & 116 & IM & IM & IM & IM & 95 \\
\hline & 17 & 77 & IM & IM & IM & IM & 94 \\
\hline \multirow[t]{3}{*}{$04 / 01 / 2010$} & 3 & 91 & IM & IM & IM & IM & 92 \\
\hline & 9 & 98 & IM & IM & IM & IM & 94 \\
\hline & 15 & 111 & IM & IM & IM & IM & 82 \\
\hline \multirow[t]{3}{*}{ 04/06/2010 } & 3 & 122 & 88 & 99 & 100 & 100 & -- \\
\hline & 9 & 100 & IM & IM & IM & IM & 91 \\
\hline & 15 & 94 & IM & IM & IM & IM & 94 \\
\hline \multicolumn{8}{|c|}{ Red River of the North near Fargo (site 2) } \\
\hline \multirow[t]{3}{*}{$03 / 23 / 2010$} & 7 & 88 & IM & IM & IM & IM & 99 \\
\hline & 17 & 78 & IM & IM & IM & IM & 93 \\
\hline & 24 & 68 & IM & IM & IM & IM & 96 \\
\hline \multirow[t]{3}{*}{$03 / 26 / 2010$} & 5 & 95 & IM & IM & IM & IM & 98 \\
\hline & 15 & 91 & IM & IM & IM & IM & 99 \\
\hline & 25 & 89 & IM & IM & IM & IM & 96 \\
\hline \multirow[t]{3}{*}{$03 / 31 / 2010$} & 5 & 121 & IM & IM & IM & IM & 95 \\
\hline & 15 & 114 & IM & IM & IM & IM & 98 \\
\hline & 25 & 127 & IM & IM & IM & IM & 95 \\
\hline \multicolumn{8}{|c|}{ Sheyenne River above Sheyenne River Diversion near Horace (site 3) } \\
\hline \multirow[t]{3}{*}{$03 / 20 / 2010$} & 3 & 451 & 87 & 96 & 100 & 100 & -- \\
\hline & 9 & 457 & 89 & 97 & 100 & 100 & -- \\
\hline & 12 & 454 & 85 & 94 & 100 & 100 & -- \\
\hline \multirow[t]{3}{*}{$03 / 23 / 2010$} & 3 & 692 & 89 & 98 & 100 & 100 & -- \\
\hline & 9 & 868 & 78 & 95 & 100 & 100 & -- \\
\hline & 14 & 810 & 84 & 96 & 100 & 100 & -- \\
\hline $03 / 26 / 2010$ & 3 & 764 & 79 & 93 & 100 & 100 & -- \\
\hline & 9 & 919 & 78 & 91 & 100 & 100 & -- \\
\hline & 15 & 864 & 79 & 93 & 100 & 100 & -- \\
\hline $03 / 29 / 2010$ & 3 & 769 & 75 & 93 & 100 & 100 & -- \\
\hline & 9 & 866 & 75 & 89 & 100 & 100 & -- \\
\hline & 15 & 724 & 78 & 93 & 100 & 100 & -- \\
\hline $03 / 31 / 2010$ & 3 & 682 & 80 & 95 & 100 & 100 & -- \\
\hline & 9 & 723 & 78 & 94 & 100 & 100 & -- \\
\hline & 15 & 649 & 87 & 98 & 100 & 100 & -- \\
\hline $04 / 05 / 2010$ & 3 & 485 & 87 & 98 & 100 & 100 & -- \\
\hline & 9 & 484 & 87 & 96 & 100 & 100 & -- \\
\hline & 15 & 522 & 87 & 94 & 100 & 100 & -- \\
\hline $04 / 07 / 2010$ & 2 & 450 & 89 & 98 & 100 & 100 & -- \\
\hline & 8 & 479 & 86 & 95 & 100 & 100 & -- \\
\hline & 14 & 474 & 87 & 96 & 100 & 100 & -- \\
\hline
\end{tabular}


Table 8. Fall diameter, sieve diameter, and suspended-sediment concentration for samples collected at discrete vertical depths during the 2010 spring high-flow event at the Red River of the North and selected tributaries near Fargo, North Dakota.—Continued [ft, feet; mm, millimeter; mg/L, milligrams per liter; IM, insufficient data for analysis; --, no value]

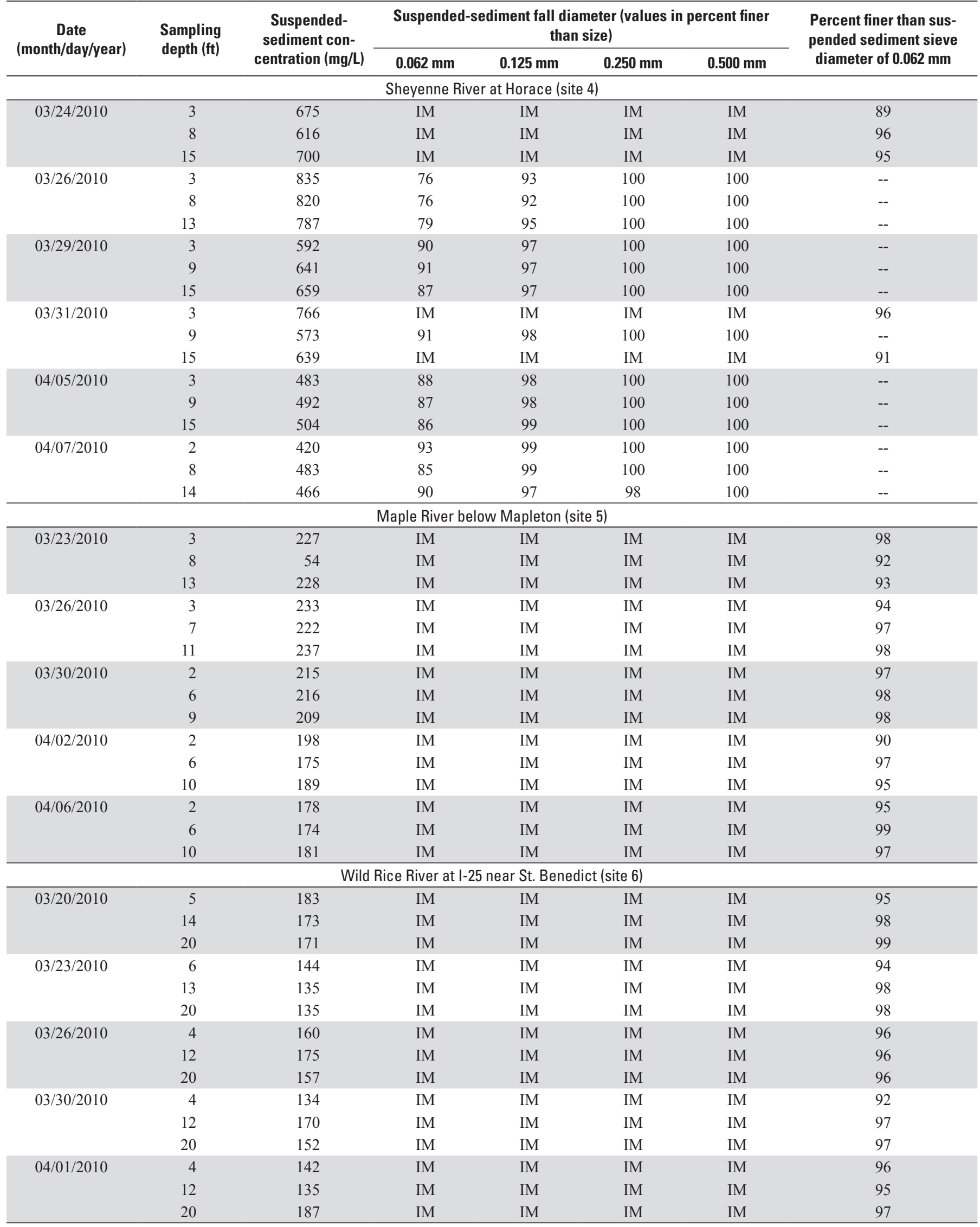


RED RIVER NEAR CHRISTINE

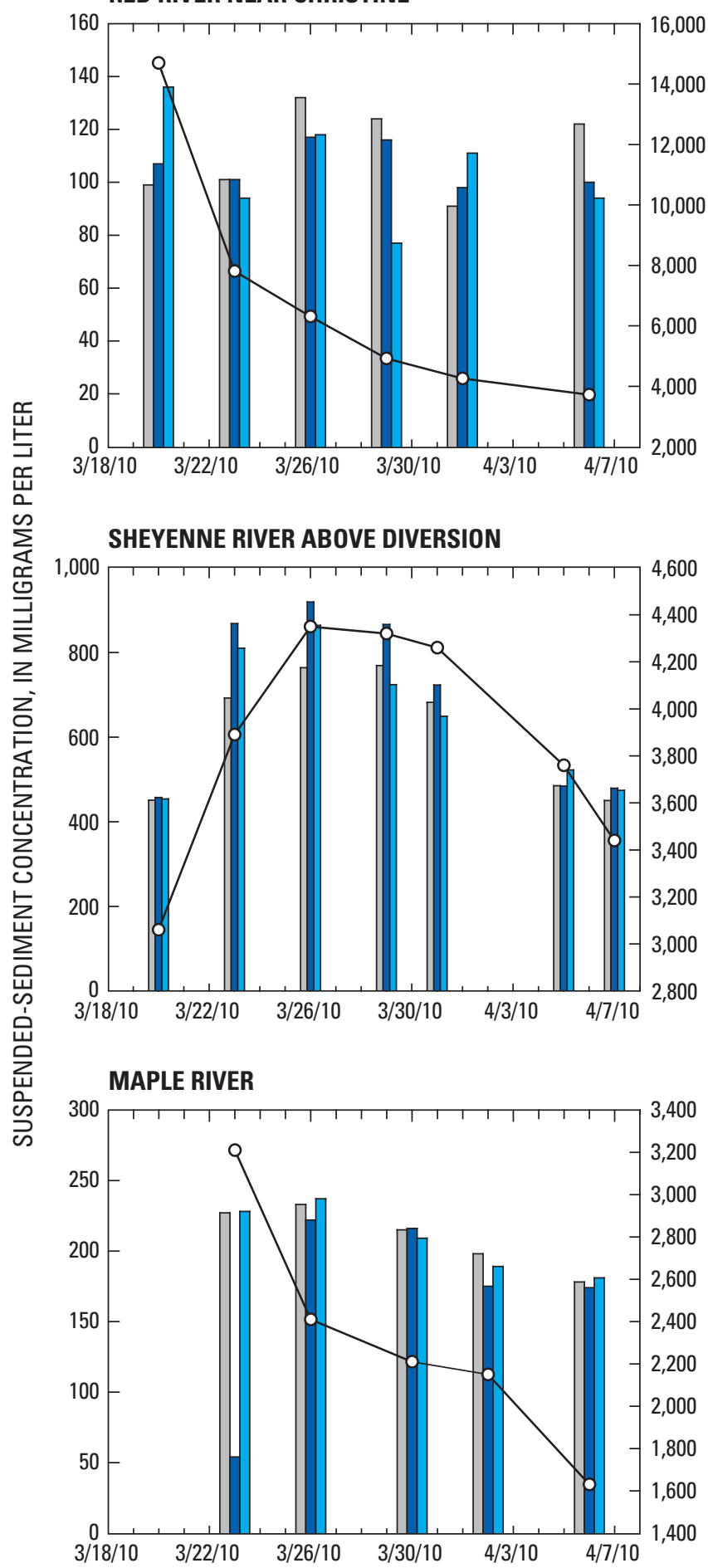

RED RIVER NEAR FARGO

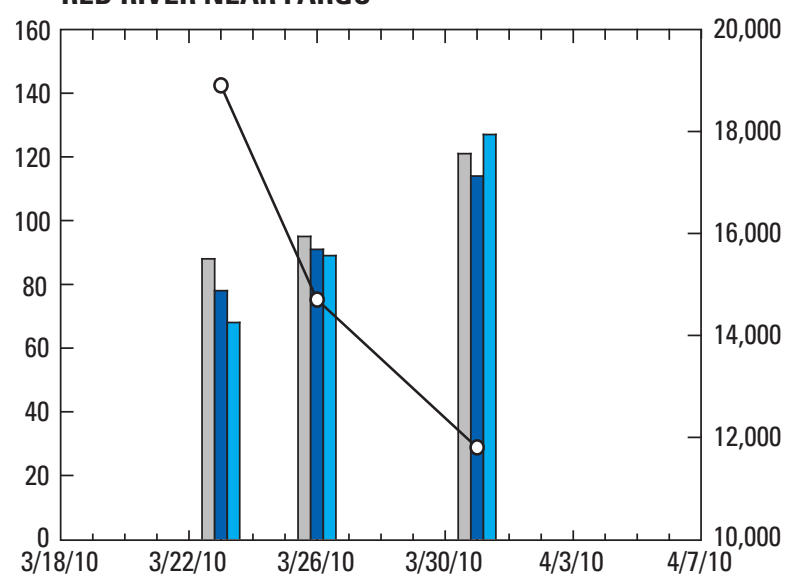

SHEYENNE RIVER BELOW DIVERSION

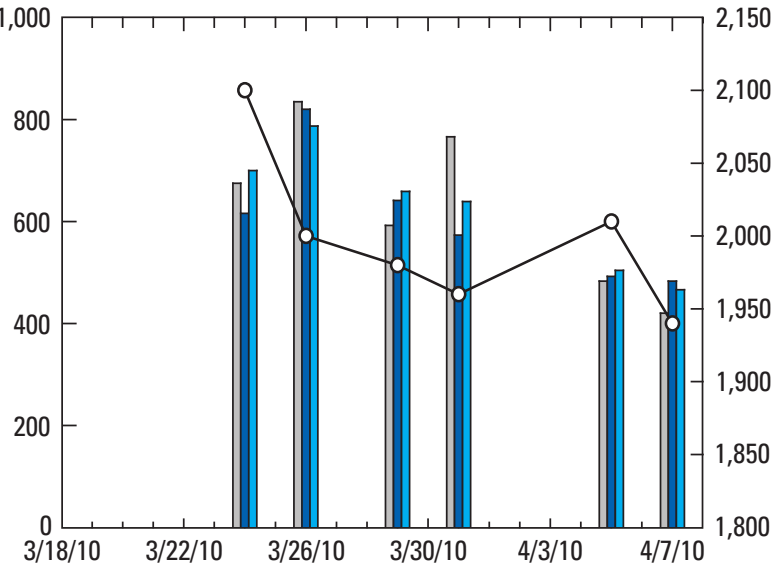

WILD RICE RIVER

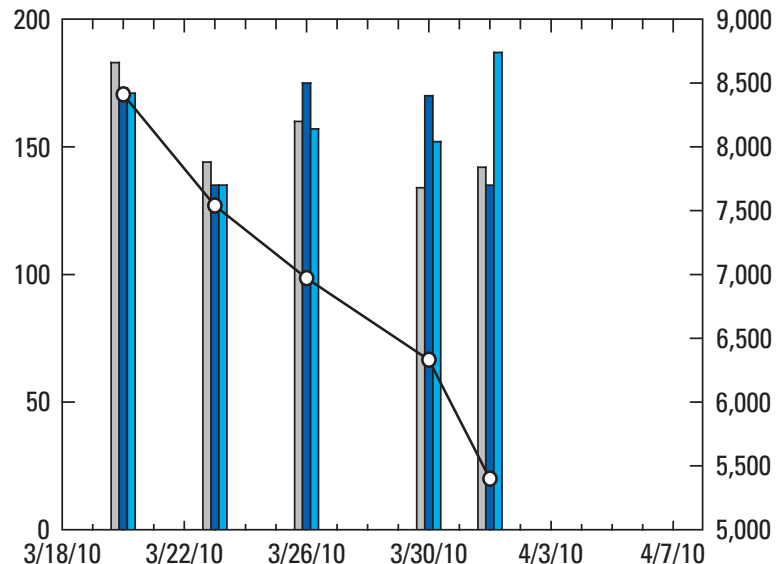

\section{EXPLANATION}

\footnotetext{
$\square$ Sample collected at approximately 20 percent of the total depth (top)

Sample collected at approximately 50 percent of the total depth (middle)

$\square$ Sample collected at approximately 80 percent of the total depth (bottom)

- Instantaneous streamflow

(middle bar represents date sample was taken)
}

Figure 7. Suspended-sediment concentrations collected at various depths above the channel thalweg in the Red River of the North and selected tributaries near Fargo, North Dakota, during the 2010 spring high-flow event. 
Table 9. Results of quality-assurance samples for suspended-sediment concentration and bedload mass for selected samples collected during the 2010 spring high-flow event at the Red River of the North and selected tributaries near Fargo, North Dakota.

[Calculation of percent difference is: $\left|\mathrm{x}_{1}-\mathrm{x}_{2} /\left(\mathrm{x}_{1}+\mathrm{x}_{2}\right) / 2\right|(100)$, where $\mathrm{x}_{1}=$ sample, $\mathrm{x}_{2}=$ sequential replicate]

\begin{tabular}{|c|c|c|c|c|}
\hline Site & $\begin{array}{c}\text { Date } \\
\text { (month/day/year) }\end{array}$ & Sample & $\begin{array}{c}\text { Sequential } \\
\text { replicate }\end{array}$ & $\begin{array}{l}\text { Percent } \\
\text { difference }\end{array}$ \\
\hline \multicolumn{5}{|c|}{ Suspended-sediment concentration (milligrams per liter) } \\
\hline Red River of the North near Christine (site 1) & $04 / 06 / 2010$ & 113 & 116 & 2.6 \\
\hline Red River of the North near Fargo (site 2) & $03 / 27 / 2010$ & 106 & 107 & .9 \\
\hline Sheyenne River above Diversion near Horace (site 3) & $03 / 29 / 2010$ & 693 & 1030 & 39.1 \\
\hline Sheyenne River above Diversion near Horace (site 3) & 04/05/2010 & 517 & 529 & 2.3 \\
\hline Sheyenne River at Horace (site 4) & $03 / 27 / 2010$ & 821 & 825 & .5 \\
\hline Maple River below Mapleton (site 5) & $03 / 27 / 2010$ & 325 & 318 & 2.2 \\
\hline Maple River below Mapleton (site 5) & $04 / 02 / 2010$ & 177 & 174 & 1.7 \\
\hline Wild Rice River near St. Benedict (site 6) & $03 / 30 / 2010$ & 148 & 151 & 2.0 \\
\hline \multicolumn{5}{|c|}{ Bedload mass (grams) } \\
\hline Sheyenne River above Diversion near Horace (site 3) & $04 / 05 / 2010$ & 56 & 410 & 151.9 \\
\hline Maple River below Mapleton (site 5) & $04 / 02 / 2010$ & 140 & 451 & 105.2 \\
\hline Wild Rice River near St. Benedict (site 6) & $03 / 30 / 2010$ & 3 & 7 & 80.0 \\
\hline
\end{tabular}

\section{Summary}

A study by the U.S. Geological Survey, in cooperation with the U.S. Army Corps of Engineers, was conducted during the 2010 spring high-flow event to determine sediment concentrations, loads, and particle-size distributions for the Red River of the North (Red River) and selected tributaries near Fargo, North Dakota. A total of six sites was sampled, including two sites on the Red River located upstream and downstream from the Fargo-Moorhead metropolitan area; two sites on the Sheyenne River, one upstream from the Sheyenne River diversion channel and one site downstream from the diversion channel; one site on the Maple River near the confluence with the Red River; and one site on the Wild Rice River near the confluence with the Red River. Suspended-sediment (point and integrated samples), bed-material, and bedload samples were collected at the six sites at various time intervals during the high-flow event.

Suspended-sediment concentrations varied spatially during the 2010 spring high-flow event sampling period. Suspended-sediment concentrations in the Red River ranged from 74 to 156 milligrams per liter at Red River near Christine and from 81 to 154 milligrams per liter at Red River near Fargo. In comparison, the suspended-sediment concentrations ranged from 476 to 1,120 milligrams per liter at the Sheyenne River above Diversion and from 505 to 957 milligrams per liter in the Sheyenne River below Diversion.

Streamflow and suspended-sediment concentration data collected during the 2010 spring high-flow event demonstrated that the timing of the peak in suspended-sediment concentration varied in relation to the peak in streamflow among the six sites. At the Red River near Christine, Red River near
Fargo, Sheyenne River below Diversion, and the Maple River, the suspended-sediment concentration peak occurred after the streamflow peak. It appears that the peak suspended-sediment concentration occurred simultaneously with the streamflow peak at the Sheyenne River above Diversion and before the streamflow peak at the Wild Rice River.

Total sediment loads measured during the 2010 spring high-flow event mainly were composed of suspended sediment and were the greatest at the Sheyenne River above Diversion compared to the loads in the Red River near Christine, Red River near Fargo, Sheyenne River below Diversion, Maple River, and the Wild Rice River. Total measured bedload for the event ranged from 7 tons at the Sheyenne River below Diversion to 186 tons at the Red River near Christine and contributed less than 1 percent of the total sediment load calculated for each of the of the sites. The calculated sediment load during the entire event ranged from 31,600 tons at the Maple River to 143,100 tons at the Sheyenne River above Diversion.

The timing of the peak in sediment discharge in relation to the peak in streamflow varied among the six sites during the 2010 spring high-flow event. Peak-sediment discharges occurred simultaneously with, or possibly prior to, the streamflow peak in the Red River near Christine, Red River near Fargo, Sheyenne River above Diversion, Maple River, and the Wild Rice River. The peak-sediment discharge occurred a day after the peak streamflow in the Sheyenne River below Diversion, and the Sheyenne River above Diversion peak sediment discharge occurred a day before the peak-sediment discharge occurred at the Sheyenne River below diversion, and simultaneously with the peak streamflow.

For the majority of all samples collected during the 2010 spring high-flow event, with the exception of the Sheyenne 
River sites, more than 90 percent of the measured suspended sediment was composed of fine-grained particles (less than 0.062 millimeters). Particle-size analyses from bedload samples indicated material in the Red River and the Maple River was coarser than material in the Sheyenne River and the Wild Rice River. The bed material demonstrated a different distribution of particle sizes than were observed in the bedload, with the coarsest material found at the Red River near Christine and the finest material at the Sheyenne River below Diversion.

Samples collected at discrete vertical depths above the channel thalweg (point samples) at six sites during the 2010 spring high-flow event demonstrated that the vertical distribution in suspended-sediment concentration varied among sites and throughout the event at each site. Differences in suspended-sediment concentration among point samples collected at various depths ranged from 6 milligrams per liter to 174 milligrams per liter. The particle sizes from sieve analyses for the Red River, Maple River, and Wild Rice River indicated that 82 to 99 percent of the suspended sediment was less than 0.062 millimeters (fine-grained particles) and did not vary substantially with depth.

\section{References Cited}

Charlton, R., 2009, Fundamentals of fluvial geomorphology: New York, Routledge, $234 \mathrm{p}$.

Colby, B.R., 1963, Fluvial sediments-A summary of source, transportation, deposition, and measurmement of sediment discharge: U.S. Geological Survey Water-Supply Paper 1498-D, 12 p.

Colby, B.R., and Hembree, C.H., 1955, Computation of total sediment discharge, Niobrara River near Cody, Nebraska: U.S. Geological Survey Water-Supply Paper 1357, 187 p.

Colby, B.R., and Hubbell, D.W., 1967, Simplified methods for computing total sediment discharge with the modified Einstein procedure: U.S. Geological Survey Water-Supply Paper 1593, $17 \mathrm{p}$.

Davis, B.E., 2005, A guide to the proper selection and use of federally approved sediment and water-quality samplers: U.S. Geological Survey Open File Report 2005-1087, 20 p.

Edwards, T.K., and Glysson, G.D., 1999, Field methods for measurement of fluvial sediment: U.S. Geological Survey Techniques of Water-Resources Investigations, book 3, chap. C2, 89 p.

Einstein, H.A., 1950, The bedload function for sediment transportation in open channel flows: U.S. Department of Agriculture Technical Bulletin 1026, $70 \mathrm{p}$.
Guy, H.P., 1969, Laboratory theory and methods for sediment analysis: U.S. Geological Survey Techniques of WaterResources Investigations, book 5, chap. C1, $58 \mathrm{p}$.

Guy, H.P., 1970, Fluvial sediment concepts: U.S. Geological Survey Techniques of Water-Resources Investigations, book 3, chap. C1, $55 \mathrm{p}$.

Helsel, D.R., and Hirsch, R.M., 1992, Statistical methods in water resources: Amsterdam, Elsevier Science Publishers, $529 \mathrm{p}$.

Hubbell, D.W., 1964, Apparatus and techniques for measuring bedload: U.S. Geological Survey Water-Supply Paper 1748, $74 \mathrm{p}$.

Kiat, C.C., Ghani, A.A.B., and Wen, L.H., 2007, Development of modified Einstein bed-load equation for sandy stream in Malaysia, $2^{\text {nd }}$ International Conference on Managing River in the $21^{\text {st }}$ Century: Solutions Toward Sustainable River Basins, p. 533-538.

Pires, L.C., and L.O. Ribeiro, 1988, Analytical evaluation of bed load transport in a river subject to backwater effect: The case of the River Trombetas in Sediment Budgets, Proceedings of the Porto Alegre Symposium, December 1988: International Association of Hydrological Sciences Publication No. 174, p. 133-138.

Porterfield, George, 1972, Computation of fluvial-sediment discharge: U.S. Geological Survey Techniques of WaterResources Investigations, book 3, chap. C3, 66 p.

Rantz, S.E, and others, 1982, Measurement and computation of streamflow: Volume 1. Measurement of stage and discharge and Volume 2. Computation of discharge: U.S. Geological Survey Water-Supply Paper 2175, 631 p.

Sen, P.K., 1968, Estimates of the regression coefficient based on Kendall's tau: Journal of the American Statistical Association, v. 63, p. 1,379-1,389.

TIBCO Software Inc., 2010, TIBCO Spotfire S+, Somerville, Massachusetts, accessed March 2011, at http://spotfire.tibco. com/products/s-plus/statistical-analysis-software.aspx.

Tornes, L.H., 1986, Suspended sediment in Minnesota streams: U.S. Geological Survey Water-Resources Investigations Report 85-4312, 33 p.

Uhrich, M.A., and Bragg, H.M., 2003, Monitoring instream turbidity to estimate continuous suspended-sediment loads and yields and clay-water volumes in the Upper North Santiam River Basin, Oregon, 1998-2000: U.S. Geological Survey Water-Resources Investigation Report 03-4098, $43 \mathrm{p}$. 
U.S. Army Corps of Engineers, 2010, Draft Fargo-Moorhead metro feasibility report and environmental impact statement: U.S. Army Corps of Engineers, St. Paul District, 190 Fifth Street East, Suite 401, St. Paul, Minnesota 55101-1638, 382 p.

U.S. Bureau of Reclamation, 2010, BORAMEP: Bureau of Reclamation Automated Modified Einstein Procedure (BORAMEP) program for computing total sediment discharge: 48 p., accessed June 1, 2010, at http://www.usbr. gov/pmts/sediment/model/boramep/index.html.

\section{Publishing support provided by:}

Rolla and Lafayette Publishing Service Centers

For additional information concerning this publication, contact: Director, USGS North Dakota Water Science Center 821 E. Interstate Ave.

Bismarck, ND 58503

(701) 250-7400

Or visit the North Dakota Water Science Center Web site at: http://nd.water.usgs.gov 




\section{总}

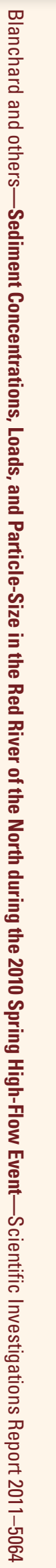

